\title{
Morphological and molecular characters to describe a marbled newt hybrid zone in the Iberian peninsula
}

\author{
Jan W. Arntzen ${ }^{1,2}$ \\ ${ }^{1}$ Naturalis Biodiversity Center, P.O. Box 9517, 2300 RA, Leiden, The Netherlands \\ ${ }^{2}$ E-mail:pim.arntzen@naturalis.nl
}

Keywords: bimodal hybrid zone, geographic clines, morphometry, moving hybrid zone, Portugal, salamander, species range, Triturus marmoratus, Triturus pygmaeus

\begin{abstract}
I document the contiguous distribution of the marbled newt species Triturus marmoratus and T. pygmaeus over the western part of the Iberian peninsula with a suite of morphological and molecular genetic data from altogether 141 populations. Morphological characters that identify the species are body size and the colour pattern character 'Links'. Links is the number of transversal connections following the green surface at the lateral sides of the newts' body. Large adults with few Links are T. marmoratus and small adults with many Links are $T$. pygmaeus. However, no morphological identification criterion is entirely adequate. Eight molecular genetic markers show markedly bimodal character state distributions that give rise to sharp species range descriptions, with T. marmoratus in the north of the Iberian peninsula and T. pygmaeus in the south and along most of the Atlantic coast of Portugal. I encountered ten genetically admixed populations that are all located at the $T$. marmoratus - T. pygmaeus species range interface, suggesting widespread but limited interspecific hybridization. A latitudinal transect across Portugal confirmed the narrow and steep transition from one to the other species for morphological and molecular characters alike. In central Portugal the position of the hybrid zone coincides with the river Tejo. However, the cline for mitochondrial DNA is relatively wide and shallow and its centre is positioned south of the river. In view of published data that reconstruct the northward advance of T.pygmaeus along the Portuguese coast at the expense of T. marmoratus, I propose that T. marmoratus had a wider range in central Portugal too, where it was eventually superseded by $T$. pygmaeus. I hypothesize that 'marmoratus' mtDNA haplotypes found south of the Tejo constitute a 'genetic footprint' left behind in T. pygmaeus by the receding species T. marmoratus.
\end{abstract}

\section{Contents}

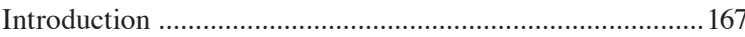

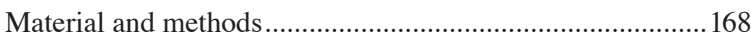

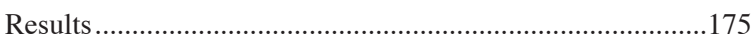

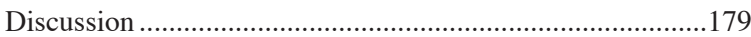

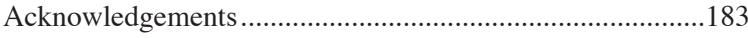

References.

Supplementary online information..................................... 185

\section{Introduction}

Hybrid zones figure prominently in evolutionary research. They are seen as "windows on evolutionary process' (Harrison, 1990) and 'natural laboratories' (Hewitt, 1988). One particular asset of hybrid zones is the opportunity they provide to evaluate the performance of new, previously untested genetic combinations of differentiated genomes in nature. Possible outcomes range from the (near-)complete merger of previously allopatric lineages to a (near-)complete genetic isolation. Debated aspects are the modes by which post-zygotic isolation accumulates and how much gene flow can be tolerated before the speciation process goes in reverse. A good group to investigate these research questions would be monophyletic, speciesrich, show contiguous species ranges where many closely as well as distantly related species engage in long hybrid zones. One group that qualifies is the European newt genus Triturus. The species group inner distribution ranges form a patchwork and most species are involved in intra-generic hybridization (Wielstra et al., 2014). The analyses over nine hybrid zones support the idea that in Triturus post-zygotic hybrid incompatibilities accumulate gradually (Arntzen et al., 2014). Results may, however, be dependent on local conditions. Moreover, for one species combination that of the northern marbled newt Triturus marmoratus (Latreille, 1800) and the pygmy marbled newt Triturus pygmaeus (Wolterstorff, 1905) - the studied transect near Madrid, Spain may be allotopic and lack hybridization altogether. I here use morphological and molecular characters to describe the marbled newt species contact across Portugal and into Spain. I show that T. marmoratus and T.pygmaeus engage in limited but widespread hybridization, not unlike crested newts in the same genus at approximately the same level of divergence (Arntzen et al., 2014). The approximately 

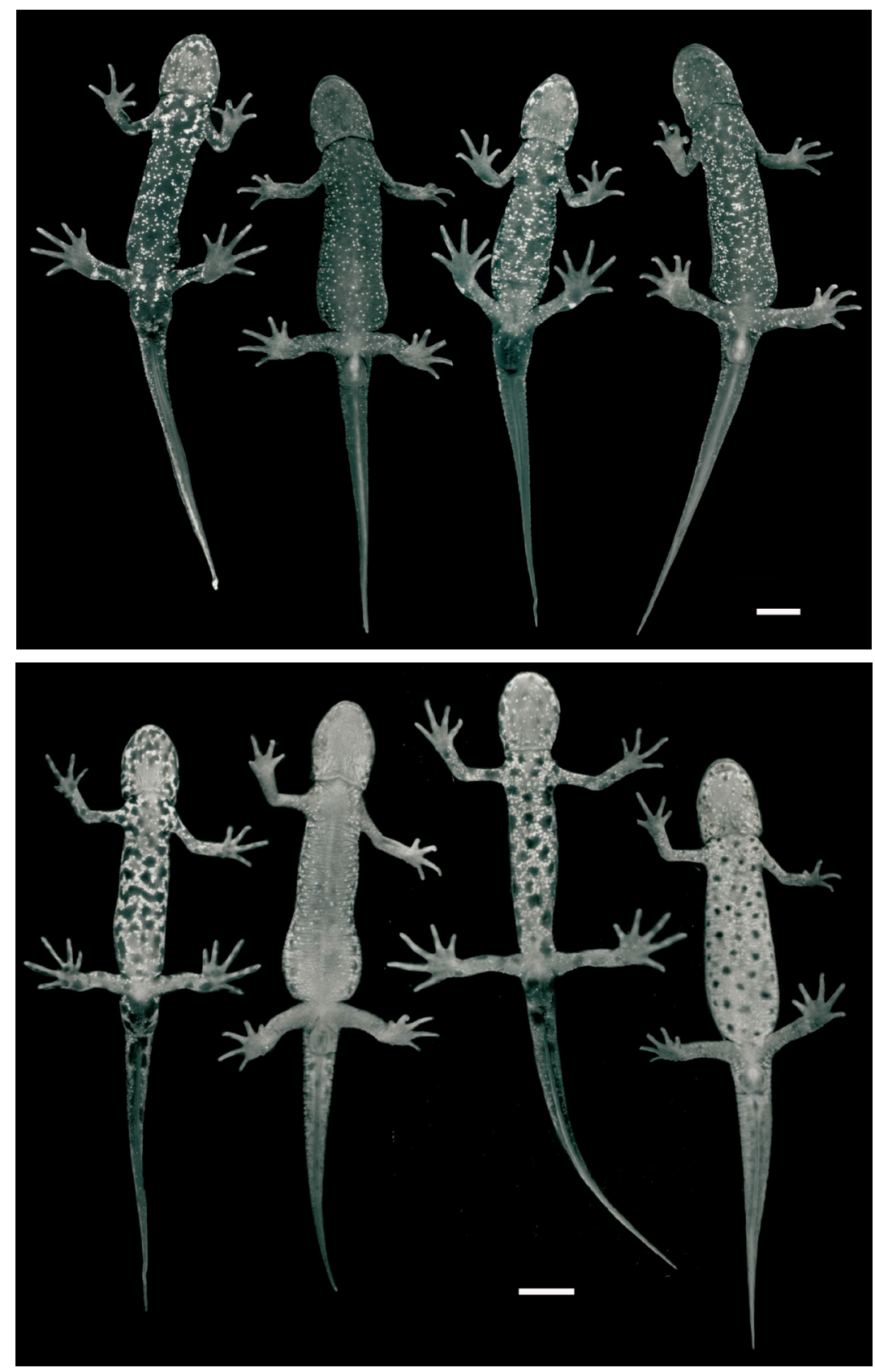

Figure 1. Ventral colouration of marbled newts with at the top row Triturus marmoratus, from left to right, male from Mayenne (western France), female from Mayenne, male from Barcelona (northeastern Spain) and female from Barcelona. Bottom row - T. pygmaeus with male from Madrid (central Spain), female from Madrid, male from Cadiz (southern Spain) and female from Cadiz. Scale bars represent $10 \mathrm{~mm}$. Colour morphology scores $\{\mathrm{Bc}, \mathrm{WSs}, \mathrm{WSn}, \mathrm{BSs}, \mathrm{BSn}\}$ given to the specimens are, in reading order $\{4,4,3,3,3\}, \quad\{5,1,2,1,1\}, \quad\{3,3,3,2,2\}$, $\{4,2,3,1,1\}, \quad\{2,5,4,4,3\}, \quad\{1,2,1,1,1\}$, $\{2,2,3,4,2\}$ and $\{1,2,3,3,2\}$. Ambiguities arise for example because absent spots have no size, when the white or black spots obscure the background colouration, when white spots aggregate as to highlight dark spots, etc. Note that I use the word 'colour' even though a black and white image captures nearly all available information.

$600 \mathrm{~km}$ long hybrid zone provides ample opportunities for further evolutionary research.

\section{Material and methods}

The morphological characters measured in marbled newts are SVl - snout-vent length up to and including the cloaca, Hl - head length, Hw - head width, ILd interlimb distance, FLl - fore limb length, TFl - third finger length, $\mathrm{HLl}$ - hind limb length and FTl - fourth toe length. Measurements were taken in $\mathrm{mm}$ with a plastic ruler (SVl, ILd) and with Vernier calipers at $0.1 \mathrm{~mm}$ precision (the other characters). Ventral side colouration characters are $\mathrm{Bc}$ - belly colour, WSn and WSs - number and size of white spots, and BSn and BSs - number and size of black spots. These characters were scored at a 1-4 or 1-5 scale, from off-white to black $(\mathrm{Bc})$, from absent or few to many (WSn and BSn) and from absent or tiny to large (WSs and BSs). To guide 
Table 1. Studied populations of marbled newts (Triturus marmoratus and T. pygmaeus) in France, Spain and Portugal, with sample sizes and results of morphological analyses. Populations marked by a hash (\#) have molecular data and are listed in Tables 2 and 3. Populations are labelled after the pond they were found, with pond numbers 2-436.

\begin{tabular}{|c|c|c|c|c|c|c|c|}
\hline $\begin{array}{l}\text { Pond cq. } \\
\text { population } \\
\text { number }\end{array}$ & Locality & Country & Longitude & Latitude & $\begin{array}{l}\text { Sample size } \\
\text { morphology }\end{array}$ & $\begin{array}{c}\text { Mean } \\
\text { discriminant } \\
\text { score }\end{array}$ & $\begin{array}{c}\text { Number of } \\
\text { newts with toe } \\
\text { abnormalities }\end{array}$ \\
\hline $2 \#$ & Rio Maior & Portugal & -8.921 & 39.341 & 65 & 0.705 & \\
\hline $3 \#$ & Alqueidão & Portugal & -8.580 & 39.530 & 20 & 0.713 & \\
\hline 4 \# & Gavião 1 & Portugal & -7.939 & 39.477 & 32 & 0.941 & \\
\hline $5 \#$ & Nisa 1 & Portugal & -7.604 & 39.533 & 4 & 0.996 & \\
\hline 6 & Sobral do Campo & Portugal & -7.549 & 39.998 & 1 & 0.990 & \\
\hline 7 \# & Pedra do Altar & Portugal & -7.821 & 39.711 & 56 & 0.030 & \\
\hline 9 & São Domingos 1 & Portugal & -8.174 & 39.603 & 22 & 0.060 & \\
\hline 10 & Montalvo & Portugal & -8.300 & 39.481 & 15 & 0.687 & \\
\hline 11 & Alfena & Portugal & -8.525 & 41.238 & 1 & 0.001 & \\
\hline $12 \#$ & Saide & Portugal & -8.329 & 40.449 & 49 & 0.018 & \\
\hline 13 & Vimeiro & Portugal & -9.019 & 39.468 & 1 & 0.631 & \\
\hline 14 & Martinchel 1 & Portugal & -8.298 & 39.538 & 4 & 0.012 & \\
\hline 15 & Andreus 1 & Portugal & -8.170 & 39.564 & 1 & 0.004 & \\
\hline 16 & Andreus 2 & Portugal & -8.170 & 39.564 & 5 & 0.064 & \\
\hline $19 \#$ & Domingos da Vinha & Portugal & -7.947 & 39.523 & 30 & 0.322 & \\
\hline 24 & Gois & Portugal & -8.111 & 40.160 & 1 & 0.005 & \\
\hline 25 & Envendos & Portugal & -7.883 & 39.582 & 4 & 0.059 & \\
\hline $26 \#$ & Lagoa Seca & Portugal & -9.012 & 39.596 & 43 & 0.598 & \\
\hline $28 \#$ & Serra de St Antonio & Portugal & -8.731 & 39.516 & 7 & 0.437 & \\
\hline $29 \#$ & Mitra 1 & Portugal & -8.001 & 38.535 & 23 & 0.992 & \\
\hline $30 \#$ & Mora & Portugal & -8.138 & 38.955 & 13 & 0.997 & \\
\hline 31 & Mindelo & Portugal & -8.727 & 41.317 & 2 & 0.482 & \\
\hline 32 \# & Gavião 2 & Portugal & -7.932 & 39.459 & 22 & 0.974 & \\
\hline 33 & Cadafaz & Portugal & -7.943 & 39.470 & 6 & 0.980 & \\
\hline 34 & Martinchel 2 & Portugal & -8.291 & 39.540 & 4 & 0.151 & \\
\hline $38 \#$ & Jublains & France & -0.472 & 48.253 & 40 & 0.052 & \\
\hline $39 \#$ & Dunes SW of Mira & Portugal & -8.785 & 40.389 & & & \\
\hline $42 \#$ & Casas de Ribeira & Portugal & -7.979 & 39.573 & 7 & 0.008 & \\
\hline 46 & dunes SW of Mira & Portugal & -8.807 & 40.324 & 4 & 0.987 & \\
\hline 48 & San Jose de Matos & Portugal & -7.845 & 39.566 & 2 & 0.958 & \\
\hline $51 \#$ & Gerês - Carris & Portugal & -8.046 & 41.815 & 71 & 0.024 & \\
\hline 52 & Zimbreirinha & Portugal & -7.873 & 39.536 & 3 & 0.966 & \\
\hline 53 & Vale Pedro Dias 2 & Portugal & -7.878 & 39.533 & 9 & 0.151 & \\
\hline $55 \#$ & Areia 2 & Portugal & -7.932 & 39.514 & 50 & 0.132 & \\
\hline 56 & Vila Flor & Portugal & -7.781 & 39.518 & 22 & 0.970 & \\
\hline 57 & Outeiro Cimeiro & Portugal & -7.901 & 39.496 & 28 & 0.042 & \\
\hline $58 \#$ & Areia 3 & Portugal & -7.934 & 39.514 & 11 & 0.137 & \\
\hline 60 & Maxial & Portugal & -7.966 & 39.563 & 1 & 0.001 & \\
\hline $62 \#$ & Coimbra & Portugal & -8.404 & 40.203 & 10 & 0.040 & \\
\hline $64 \#$ & Degracias - Casas de S. Jorge & Portugal & -8.521 & 40.007 & & & \\
\hline $65 \#$ & Vila do Bispo - Sagres & Portugal & -8.904 & 37.072 & 31 & 0.964 & \\
\hline $66 \#$ & Nisa 2 & Portugal & -7.593 & 39.550 & 17 & 0.962 & \\
\hline 67 \# & Rosmaninhal & Portugal & -7.091 & 39.732 & 40 & 0.976 & \\
\hline 68 & Monforte da Beira & Portugal & -7.300 & 39.738 & 1 & 0.841 & \\
\hline 69 \# & Soure & Portugal & -8.639 & 40.032 & & & \\
\hline $70 \#$ & Monte do Conde & Portugal & -7.250 & 40.167 & 12 & 0.015 & \\
\hline $72 \#$ & João Pires & Portugal & -7.154 & 40.106 & 17 & 0.024 & \\
\hline
\end{tabular}


Table 1 continued

\begin{tabular}{|c|c|c|c|c|c|c|c|}
\hline $\begin{array}{l}\text { Pond cq. } \\
\text { population } \\
\text { number }\end{array}$ & Locality & Country & Longitude & Latitude & $\begin{array}{l}\text { Sample size } \\
\text { morphology }\end{array}$ & $\begin{array}{c}\text { Mean } \\
\text { discriminant } \\
\text { score }\end{array}$ & $\begin{array}{c}\text { Number of } \\
\text { newts with toe } \\
\text { abnormalities }\end{array}$ \\
\hline 73 & Medelim - Penha Garcia nr. Sidral & Portugal & -7.111 & 40.053 & 2 & 0.067 & \\
\hline 76 \# & São João do Deserto & Portugal & -7.198 & 40.144 & 5 & 0.005 & \\
\hline 80 \# & Barragem de Idanha-a-Nova & Portugal & -7.192 & 39.936 & 42 & 0.222 & \\
\hline 81 \# & Sra. do Almortão 1 & Portugal & -7.206 & 39.907 & & & \\
\hline 84 \# & Zebreira & Portugal & -7.091 & 39.913 & 44 & 0.968 & \\
\hline 87 \# & Soverete & Portugal & -7.286 & 39.262 & 4 & 0.886 & \\
\hline 88 \# & Mourão & Portugal & -7.312 & 38.429 & 3 & 0.996 & \\
\hline 90 \# & Esperança & Portugal & -7.174 & 39.176 & 34 & 0.905 & \\
\hline 91 \# & Castelo Mendo & Portugal & -6.933 & 40.598 & 21 & 0.060 & \\
\hline 92 \# & Mogadouro & Portugal & -6.740 & 41.332 & 25 & 0.011 & \\
\hline 93 \# & Granja & Portugal & -7.262 & 38.318 & 11 & 0.986 & \\
\hline 94 \# & Mitra 2 & Portugal & -8.001 & 38.535 & 22 & 0.978 & \\
\hline 95 \# & Aldeia Santa Margarida & Portugal & -7.274 & 40.050 & 21 & 0.082 & \\
\hline 96 \# & Ponte Maceira, Negreira & Spain & -8.703 & 42.901 & 10 & 0.010 & \\
\hline 97 \# & Calvão & Portugal & -8.705 & 40.460 & 26 & 0.847 & 1 \\
\hline 98 \# & Quiaios & Portugal & -8.816 & 40.237 & 20 & 0.890 & \\
\hline 99 \# & Praia de Vagueira & Portugal & -8.740 & 40.569 & & & \\
\hline $100 \#$ & Madeirã & Portugal & -8.101 & 39.937 & 24 & 0.000 & \\
\hline $102 \#$ & Nespereira de Baixo - Borallal & Portugal & -8.350 & 40.757 & 21 & 0.007 & \\
\hline $103 \#$ & Mezio & Portugal & -7.885 & 40.979 & 28 & 0.002 & \\
\hline 104 \# & Velada & Portugal & -7.701 & 39.580 & 22 & 0.965 & \\
\hline 105 \# & Fratel - Carepa & Portugal & -7.761 & 39.630 & & & \\
\hline $106 \#$ & Carepa & Portugal & -7.773 & 39.626 & & & \\
\hline 107 \# & Vila Velha de Rodão & Portugal & -7.667 & 39.668 & 40 & 0.899 & \\
\hline 108 \# & Vale de Figueira & Portugal & -7.747 & 39.681 & 31 & 0.005 & \\
\hline 109 \# & Vilar de Boi & Portugal & -7.736 & 39.672 & & & \\
\hline $110 \#$ & Zebreira West & Portugal & -7.112 & 39.839 & & & \\
\hline $114 \#$ & Torreira & Portugal & -8.710 & 40.764 & & & \\
\hline $116 \#$ & Porto - Botanical Garden & Portugal & -8.642 & 41.153 & & & \\
\hline $119 \#$ & Salir de Matos & Portugal & -9.083 & 39.427 & 1 & 0.000 & \\
\hline $121 \#$ & Fonte da Pena da Couvinha & Portugal & -9.019 & 39.477 & 2 & 0.001 & \\
\hline $122 \#$ & Punta Moreiras & Spain & -8.876 & 42.497 & 8 & 0.040 & \\
\hline $127 \#$ & Mosteiros de Alcanede & Portugal & -8.838 & 39.426 & 6 & 0.523 & \\
\hline 134 \# & Aceitunas & Spain & -6.317 & 40.152 & 8 & 1.000 & \\
\hline $135 \#$ & Santa Cruz de Paniagua & Spain & -6.335 & 40.201 & 7 & 0.937 & 2 \\
\hline $136 \#$ & El Bronco & Spain & -6.333 & 40.218 & 21 & 0.991 & 1 \\
\hline $138 \#$ & Pedro Muñoz 2 & Spain & -6.343 & 40.275 & & & \\
\hline $139 \#$ & Pedro Muñoz 3 & Spain & -6.340 & 40.257 & & & \\
\hline $141 \#$ & Puerto Nuevo & Spain & -6.536 & 40.361 & & & \\
\hline $145 \#$ & Alcuescar & Spain & -6.242 & 39.184 & 25 & 0.925 & 1 \\
\hline $146 \#$ & Rexaldia 1 & Portugal & -8.548 & 39.572 & 2 & 0.951 & \\
\hline 147 \# & Rexaldia 2 & Portugal & -8.549 & 39.571 & 10 & 0.960 & 1 \\
\hline $148 \#$ & Assertiz - Fungalvaz & Portugal & -8.515 & 39.598 & 20 & 0.868 & \\
\hline 150 & Covão da Fonte & Portugal & -8.802 & 39.538 & 2 & 1.000 & \\
\hline 151 & Carrascal - Évora de Alcobaça 1 & Portugal & -8.961 & 39.531 & 2 & 0.804 & \\
\hline 152 & Molianos & Portugal & -8.920 & 39.507 & 1 & 0.185 & \\
\hline 153 & Covas & Portugal & -8.802 & 39.533 & 16 & 0.559 & \\
\hline
\end{tabular}


Table 1 continued

\begin{tabular}{|c|c|c|c|c|c|c|c|}
\hline $\begin{array}{l}\text { Pond cq. } \\
\text { population } \\
\text { number }\end{array}$ & Locality & Country & Longitude & Latitude & $\begin{array}{l}\text { Sample size } \\
\text { morphology }\end{array}$ & $\begin{array}{c}\text { Mean } \\
\text { discriminant } \\
\text { score }\end{array}$ & $\begin{array}{c}\text { Number of } \\
\text { newts with toe } \\
\text { abnormalities }\end{array}$ \\
\hline 155 & Casais Monizes & Portugal & -8.896 & 39.449 & 11 & 0.459 & \\
\hline 157 & Carrascal - Évora de Alcobaça 2 & Portugal & -8.960 & 39.532 & 2 & 0.723 & \\
\hline 160 & Juncal 2 & Portugal & -8.916 & 39.597 & 7 & 0.266 & \\
\hline 165 & Andam & Portugal & -8.897 & 39.619 & 1 & 0.734 & \\
\hline 177 & Carrascal 2 & Portugal & -7.878 & 39.547 & 1 & 0.010 & \\
\hline 186 & Zimbreira & Portugal & -7.849 & 39.576 & 1 & 0.000 & 1 \\
\hline $196 \#$ & Serradilla del Llano & Spain & -6.319 & 40.482 & 14 & 0.080 & 3 \\
\hline 202 & Mação 1 & Portugal & -7.976 & 39.513 & 2 & 0.259 & \\
\hline 203 \# & Mação - Belver & Portugal & -7.980 & 39.538 & 1 & 0.001 & \\
\hline $205 \#$ & Tomar & Portugal & -8.418 & 39.602 & 46 & 0.841 & 6 \\
\hline 206 & Cem Soldos & Portugal & -8.458 & 39.585 & 1 & 0.594 & \\
\hline $208 \#$ & Sintra 1 & Portugal & -9.418 & 38.793 & & & \\
\hline 209 \# & Sintra 2 & Portugal & -9.388 & 38.788 & 15 & 0.660 & 2 \\
\hline 216 & Olas & Portugal & -8.339 & 39.665 & 2 & 0.000 & \\
\hline $217 \#$ & Nelas, Ponte Nove & Portugal & -7.836 & 40.486 & 21 & 0.014 & 1 \\
\hline $218 \#$ & Casar de Palomera 1 & Spain & -6.241 & 40.278 & 4 & 0.010 & \\
\hline $219 \#$ & Casar de Palomera 2 & Spain & -6.251 & 40.272 & 3 & 0.110 & \\
\hline 221 & Marchagaz & Spain & -6.270 & 40.270 & 1 & 0.002 & \\
\hline $222 \#$ & Palomero & Spain & -6.250 & 40.273 & 11 & 0.997 & \\
\hline $224 \#$ & Santa Catarina & Portugal & -8.357 & 39.651 & 4 & 0.075 & \\
\hline 225 & Casais & Portugal & -8.383 & 39.654 & 1 & 0.002 & \\
\hline 243 & Praia de Vagueira 2 & Portugal & -8.740 & 40.568 & 10 & 0.714 & \\
\hline 244 & Albergaria dos Doze & Portugal & -8.612 & 39.797 & 2 & 0.064 & \\
\hline 245 & Montalvao - Spanish border & Portugal & -7.531 & 39.609 & 17 & 0.973 & \\
\hline 247 & Castelo de Vide railway line 1 & Portugal & -7.479 & 39.444 & 13 & 0.995 & \\
\hline 248 & Beira & Portugal & -7.360 & 39.451 & 2 & 0.871 & \\
\hline 250 & São Domingos 2 & Portugal & -8.171 & 39.602 & 11 & 0.101 & \\
\hline 257 & Carreiras & Portugal & -7.457 & 39.371 & 2 & 1.000 & \\
\hline 271 & Doñana & Spain & -6.394 & 36.853 & 31 & 0.949 & \\
\hline $273 \#$ & Archidona_Loja & Spain & -4.287 & 37.130 & & & \\
\hline 300 & Olhos de Agua & Portugal & -7.383 & 39.371 & 16 & 0.974 & \\
\hline 307 & Castelo de Vide railway line 2 & Portugal & -7.444 & 39.455 & 10 & 0.954 & \\
\hline $336 \#$ & Confolens & France & 0.667 & 46.017 & & & \\
\hline 337 \# & El Berrueco & Spain & -3.883 & 40.900 & & & \\
\hline 338 \# & Puerto de Galiz & Spain & -5.450 & 36.683 & & & \\
\hline 339 \# & Rochechouart & France & 0.833 & 45.817 & & & \\
\hline $340 \#$ & Venta del Charco & Spain & -4.267 & 38.200 & & & \\
\hline $341 \#$ & Zafarraya & Spain & -4.133 & 36.967 & & & \\
\hline 354 & Marinha Grande & Portugal & -8.924 & 39.750 & 1 & 0.005 & \\
\hline 436 & Umbria near Monchique & Portugal & -8.506 & 37.335 & 1 & 0.996 & \\
\hline 438 & Faro University 1 & Portugal & -7.979 & 37.050 & 2 & 1.000 & \\
\hline 453 & Picarras & Portugal & -8.563 & 38.680 & 2 & 0.990 & \\
\hline 454 & Fuenlabrada de los Montes & Spain & -4.956 & 39.129 & 2 & 1.000 & \\
\hline 458 & Los Baños del Robledillo & Spain & -4.358 & 39.496 & 1 & 0.987 & \\
\hline 459 & Buenasbodas nr. Belvis de la Jara & Spain & -4.890 & 39.681 & 3 & 0.974 & \\
\hline 461 & Los Yebenes - estacion de Urda & Spain & -3.821 & 39.418 & 20 & 0.992 & \\
\hline 463 & Villanueva de San Juan - Moron & Spain & -5.289 & 37.060 & 1 & 0.966 & \\
\hline
\end{tabular}


the reader of what the colour classifications are like see Figure 1. Note that the image in black and white captures nearly all ventral 'colour' information. Since these characters are continuous, borderline cases are not infrequent. Dorso-lateral colour pattern characters are 'Links' and 'Toplinks'. Links is the number of uninterrupted transversal connections following the green coloured surface at the lateral side of the body. Links were counted over both body sides independently, over the section of the body covered by ILd. Toplinks is the number of dark spots that reach up to the mid-dorsal line and make it at least half way down the side and are also counted over both sides of the body. Illustrations of these characters are in Figure 2.

The morphometric data were ln-transformed. In order to analyze predominantly shape and not size, I calculated the standardized residuals of the regression of 'In character' on lnSVl. Males and females were
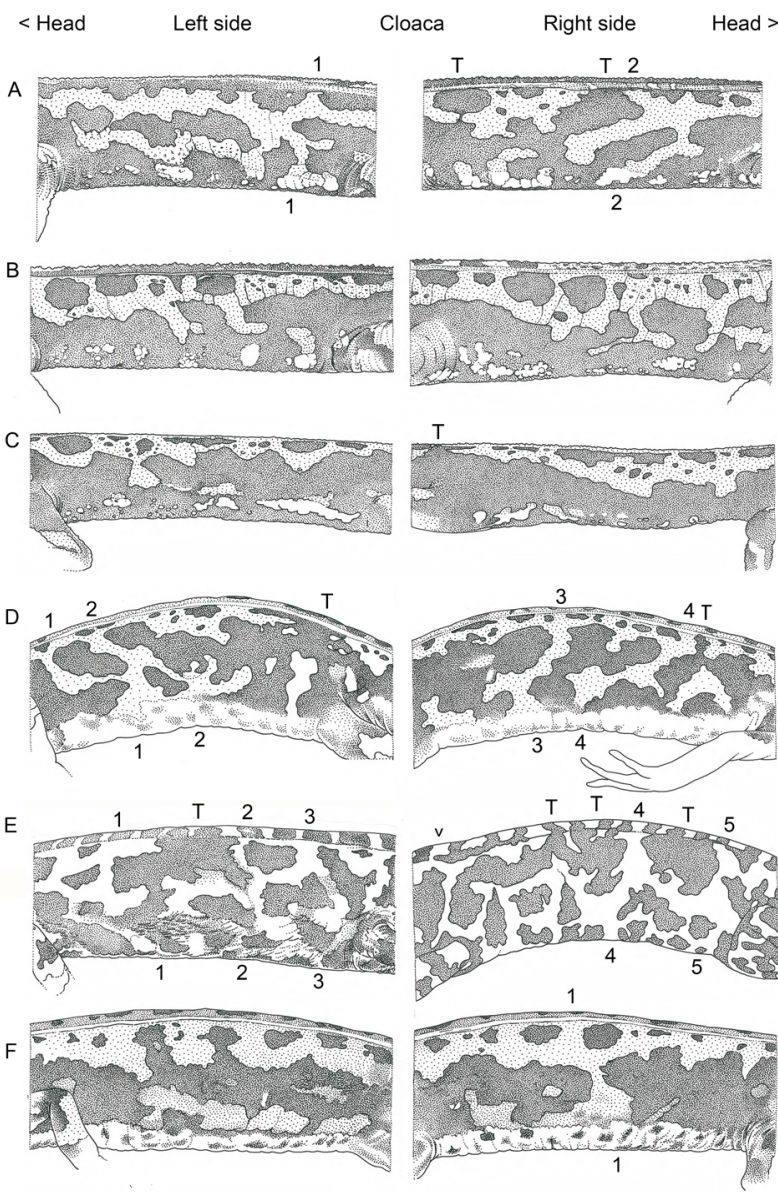
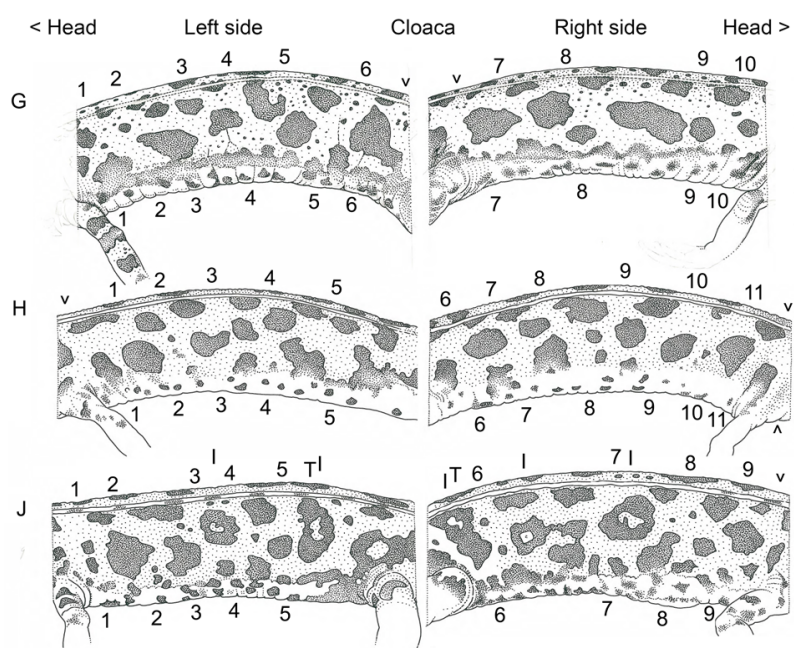

K
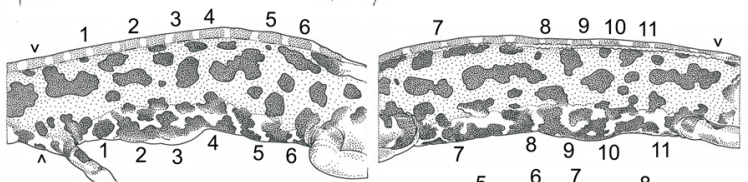

L
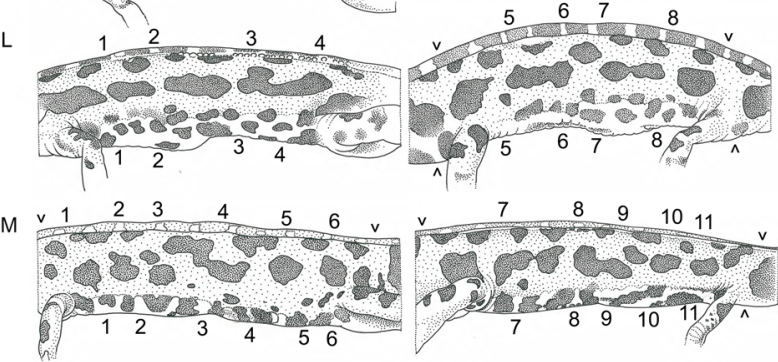

Figure 2. Line drawings of the dorso-lateral sides of adult marbled newts. The dominant colours green and brown are shown by light and dark shading, respectively. On the left are Triturus marmoratus from Gerês in northern Portugal (A-C, locality 51) and Casas de Ribeira at the northern side of the contact zone (D-F, locality 42). On the right are T. pygmaeus from Gavião at the southern side of the contact zone (G, H and J, locality 32) and from Vale de Bispo - Sagres in southern Portugal (K-M, locality 65). The imagery illustrates how Links (numbers) and Toplinks (T) are counted. Links are the transversal connection following the green surface at the lateral side of the newts' body and are indicated by numbers $(1-1,2-2$, etc.). Tick marks $(\wedge)$ to the left and right indicate genuine Links, but these are not counted because they fall (partly) outside the area covered by the measure interlimb distance. Toplinks are the dark spots that touch the mid-dorsal line and reach at least halfway down the newt's lateral side. Ambiguities in counting Links include the often vague colour transition from the lateral to the ventral side. This did not preclude recognizing links, such as Link 3 in specimen E. In specimen K Links 8 and 9 could also have been scored as a single one, because the Link paths share a short section in the middle. In counting Toplinks ambiguities may also arise, such as in specimen A where for the first Toplink the connection over the side is thin and in specimen $\mathrm{J}$ where it is arbitrary if the second Toplink reaches the mid-dorsal line. Reticulated (or 'wavy') colour patterns such as in specimen E and to a lesser extent in specimen D were only observed in the zone of contact and are tentatively associated with interspecific hybridization. Also 'colour islands' (I) such as in specimen J were found exclusively in and around the contact zone. 
analyzed separately because of a documented sexual size dimorphism (García-París et al., 1993). Altogether data were gathered for 1690 adult individuals in one French, 17 Spanish and 101 Portuguese populations (average $\mathrm{N}=14.2$, range 1-71). The populations studied are listed in Table 1. However, colouration character states were defined during the project and are missing for 143 individuals $(8.5 \%)$. Occasionally, Links or Toplinks could not be counted due to albinism $(\mathrm{N}=1$, population 51), melanism ( $\mathrm{N}=9$, populations 122,151 , 157, 165 and 206), or because of an aberrant, highly fragmented colouration pattern $(\mathrm{N}=2$, population 307). The green dorso-lateral colour is overall darker and harder in T. marmoratus than the softer, olive shades of green that are prevalent in T. pygmaeus, but I was unable to score this character consistently. The tuberculate versus smooth skins and thick versus thin arms and legs for respectively $T$. marmoratus and $T$. pygmaeus were difficult to describe and also remained unrecorded. Finally, notes were taken on morphological abnormalities of fingers and toes, because these may be indicative of hybridization, as is the case of $T$. marmoratus and T.cristatus (Laurenti, 1768) in central France (Vallée, 1959; Arntzen and Wallis, 1991). To obtain an indication of measurement error 21 marbled newts were measured by myself in duplicate and by two volunteer students. To estimate measuring error the untransformed data were analyzed by principal component analysis, in SPSS v. 20 (IBM SPSS, 2016).

To be able to evaluate the diagnostic properties of the morphological data I also gathered data for enzyme genetic markers with proven performance for species identification, following Espregueira Themudo and Arntzen (2007a). The four marker loci that differentiated T. marmoratus from T.pygmaeus are PepA with reported $x$ values (Cohen's kappa, Cohen, 1960) $x=0.92$, РерB with $x=0.97, P e p D$ with $x=0.12$ and $L d h 2$ with $x=0.56$. A total of 896 individuals was studied for ten Spanish and 46 Portuguese populations (average $\mathrm{N}=16.0$, range 1-41). Tissues investigated were tail tips taken from adults. Missing data amounted to $3.4 \%$, with no more than one locus with missing data for any individual. The individual genotypes are in Online Supplementary Information SI. DNA sequences of the nuclear genes B-fibrinogen intron 7 (FGBIT7, or $B F$ ), calreticulin intron 3 (CALRIT3, or CALR), platelet-derived growth factor receptor a-intron 11 (PDGFRAIT11, or $P D G$ ) and the mitochondrial gene NADH dehydrogenase subunit 4 (ND4) were taken from the literature (Espregueira Themudo et al., 2012). A total of 1325 sequences were downloaded from Genbank and aligned with Clustal $\Omega$
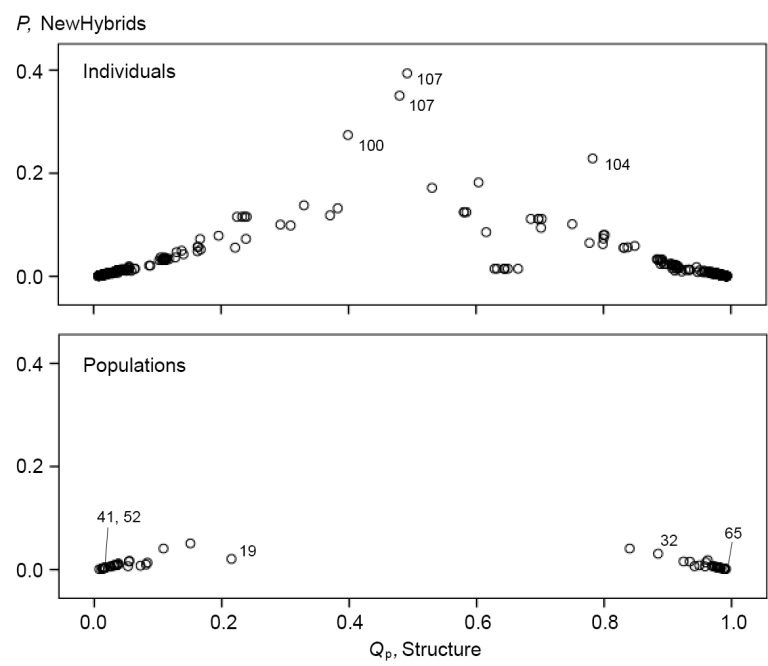

Figure 3. Bivariate scatter plots of molecular genetic classifications obtained with Structure $\left(Q_{\mathrm{p}}\right.$-scores along the horizontal axis) and NewHybrids ( $P$-values along the vertical axis). Low and high $Q_{\mathrm{p}}$-scores refer to Triturus marmoratus and T. pygmaeus, respectively. Note that 35 (3.9\%) individuals and one population $(1.8 \%)$ score as genetically admixed $(0.2$ $\left.<Q_{\mathrm{p}}<0.8\right)$. Top panel - results for individuals $(\mathrm{N}=894)$. Four individuals with relatively high hybridity $(\mathrm{P}>0.2)$ are indicated by their population number. Bottom panel - results averaged for populations $(\mathrm{N}=56)$. Four populations for which individual newts are shown in Figure 2 are indicated by their numbers. Population 19 classifies as admixed; see also Table 2.

(Sievers and Higgins, 2014). Median joining haplotype networks were constructed for each sequenced marker with PopArt (Bandelt et al., 1999; Leigh and Bryant, 2015). The internal node was located that maximized the separation between T. marmoratus and T. pygmaeus individuals from non-admixed populations. The fit of the haplotype groups to the species was $\chi=0.87$ for $B F$, $x=0.96$ for $C A L R, x=0.66$ for $P D G$ and $x=0.93$ for $N D 4$. A total of 79 populations have sequence data available.

Species differentiation, population diversity and admixture were explored with the Bayesian clustering algorithm Structure (Pritchard et al., 2000) with a predetermined $K=2$ number of groups, reflecting the species to be analyzed and the known diagnostic properties of the marker loci. The data were also analyzed with NewHybrids (Anderson and Thompson, 2002) under default settings, to identify possible cases of hybridization. The classes recognized were T. marmoratus, $T$. pygmaeus and a hybrid class composed of pooled $\mathrm{F}_{1}$ 's, $\mathrm{F}_{2}$ 's and backcross hybrid individuals. Structure $Q$-values in the 0.2 - 0.8 range and NewHybrid $P_{\mathrm{NH}}$ values $>0.5$ were interpreted as 


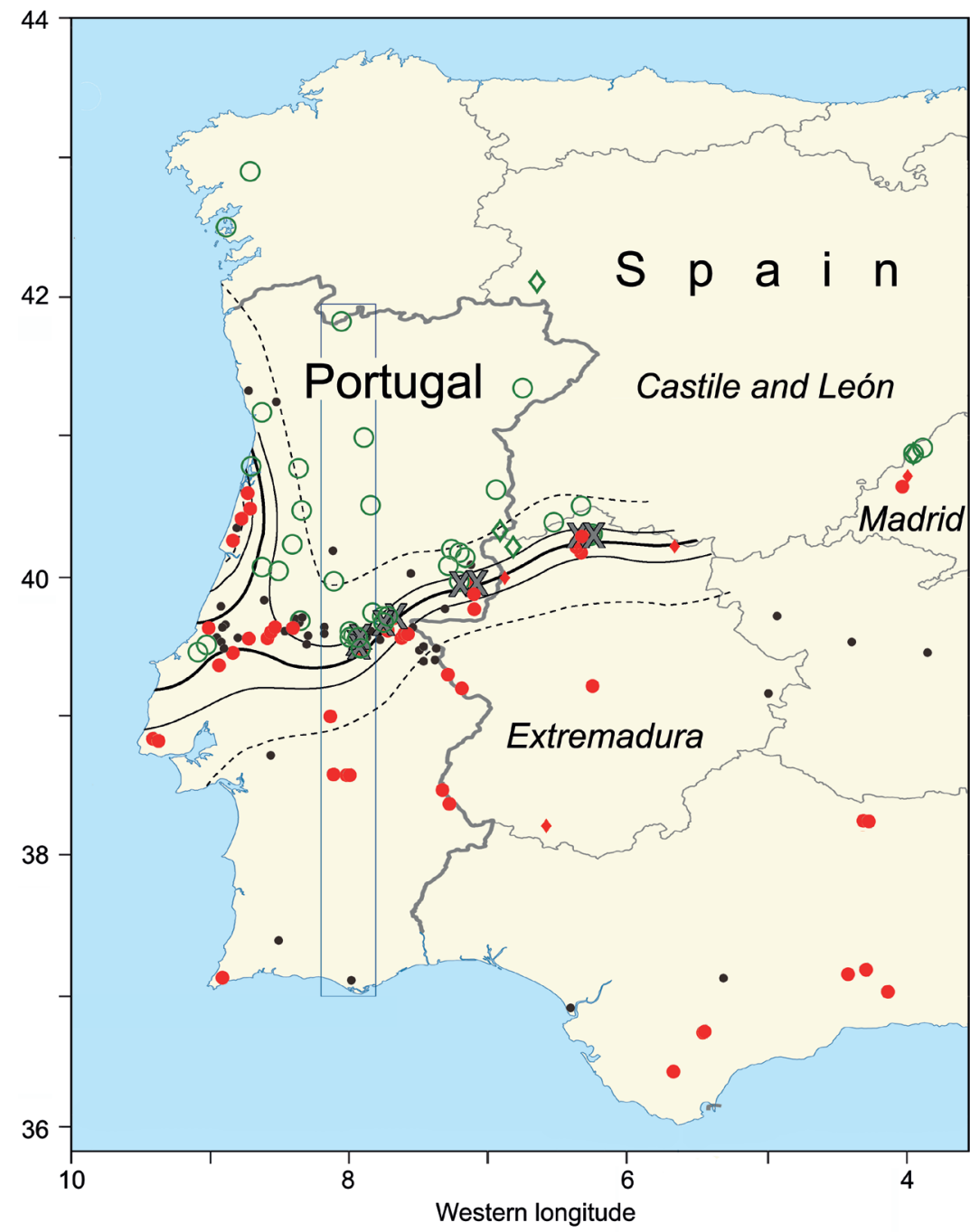

Figure 4. Western part of the Iberian Peninsula in quadrangular projection. Coloured symbols refer to genetically identified populations, with Triturus marmoratus shown by open green circles, $T$. pygmaeus by solid red circles and admixed populations by an $\mathrm{X}$. Green and red diamond symbols refer to published data by (García-París et al. 2001; Arntzen et al. 2001). Small black dots are populations with morphological data only. Projected lines summarize the results of the discriminant analysis of morphological data, with the probability for classification as Triturus marmoratus, $P_{\mathrm{m}}=P_{\mathrm{p}}=0.5$ shown by a solid line, $P=0.4$ and 0.6 shown by thin lines and $P_{\mathrm{p}}^{\mathrm{p}}=0.2$ and 0.8 by interrupted lines, with $T$. marmoratus to the north and T. pygmaeus to the south and southwest. The transect for the analysis of geographical clines is indicated by the box with coordinates 7.8 -8.2 western longitude and $37.0-42.0$ northern latitude. evidence for recent (NewHybrids) or possibly more ancient (Structure) hybridization and interspecific gene flow. The basic population genetic analyses for Hardy-Weinberg and linkage (dis)equilibrium were carried out with GenePop (Raymond and Rousset, 1995) under population-wide Bonferroni correction.

The morphological data were analyzed by univariate and stepwise discriminant analysis in SPSS with Structure individual allocations to T. marmoratus $\left(Q_{\mathrm{p}}<0.2\right), T$. pygmaeus $\left(Q_{\mathrm{p}}>0.8\right)$ or unknown. The 'unknowns' were either genetically admixed with $Q$-scores in the $0.2-0.8$ range, or had no genetic data available. The unknowns were classified $a$ posteriori from their morphology discriminant scores as T. marmoratus $\left(P_{\mathrm{DAp}}<0.2\right)$, T. pygmaeus $\left(P_{\mathrm{DAp}}>\right.$ $0.8)$ or intermediate $\left(0.2<P_{\text {DAp }}<0.8\right)$. The fit of the morphological to the genetic species identification was assessed with the AUC (area under the curve) statistic in SPSS. Ellipses summarizing variation around the mean in bivariate plots were produced with Mystat 12 software (Mystat, 2007). Spatial contour maps were also made with Mystat, under default settings and with population data weighted for sample size.

Geographical clines were calculated for populations in a south to north transect across Portugal, encompassed by the coordinates $37.0-42.0 \mathrm{~N}$ and $7.8-8.2 \mathrm{~W}$. I performed maximum likelihood geographical cline analyses with the R package HZAR (Derryberry et al., 2014). Clines were fitted on probabilities of species assignment for morphological data from discriminant analysis $\left(P_{\mathrm{DAp}}, 31\right.$ populations), on Structure scores for the enzyme loci $\left(Q_{\mathrm{p}}, 14\right.$ populations) and on the 
frequencies of species indicative haplotype groups for sequence data ( $F_{\mathrm{p}}$, eigth populations) with values running from zero ( $T$. marmoratus) to unity (T. pygmaeus). Clines were also fitted for the best performing morphological characters individually (SVl and Links, 27-29 populations, see below). The shape of each cline is described as a sigmoidal curve with a centre (maximum slope) and two tails (one in each side) modelled as an exponential decay, following Szymura and Barton (1986). Five different models were tested, varying on the presence/absence of left and right tails and their symmetry/asymmetry. Additionally, minimum $\left(P_{\text {min }}\right)$ and maximum $\left(P_{\max }\right)$ character values were used to scale cline models in three different ways: with empirical estimates (using lower and higher observed values in the data), with best-fit values, and with no scaling. The combination of cline shapes and scaling thus produces a total of 15 different models for each cline, plus a null model (see for instance Prada and Hellberg, 2014). The Metropolis-Hasting algorithm in HZAR was run for the default value of 100,000 steps with a randomly selected seed and a burn-in of $10 \%$. Given the uneven sample sizes it is important to note that HZAR cline estimates are made with sample size taken into account. After each run, I recorded the corrected Akaike Information Criterion score for each model within each cline and chose the one with the lowest score to infer cline width, cline centre and other cline shape parameters.

\section{Results}

Deviations from Hardy-Weinberg equilibrium with deficiencies of heterozygotes were found for the loci $P e p B$ and $P e p D$ in population 56. Significant linkage disequilibrium was not observed. With the Bayesian clustering algorithm Structure 393 individuals were classified as T. marmoratus $\left(Q_{\mathrm{p}}<\right.$ $0.2), 466$ were classified as $T$. pygmaeus $\left(Q_{\mathrm{p}}>0.8\right)$ and 35 were admixed. At the population level 27 were T. marmoratus, 28 were T. pygmaeus and one was admixed (population 19, Table 2, Figure 3). With NewHybrids individuals and populations were allocated to the non-hybrid class (either T. marmoratus or T. pygmaeus), though four individuals (and no populations) showed a weak signal with $P_{\mathrm{NH}}$ values in the $0.2-0.5$ range. The DNA sequence data allocated 34 populations to $T$. marmoratus, 36 to $T$. pygmaeus and nine were admixed (Table 3 ). The resulting species distribution is strongly partitioned with T. marmoratus
Table 2. Structure $Q$-scores derived from four enzyme loci (LDH2, PEPA, PEPB and PEPD) along with sample sizes and classification results, with $\mathrm{m}$ - Triturus marmoratus (27 populations with $Q_{\mathrm{p}}<0.20$ ), $\mathrm{p}-T$. pygmaeus (28 populations with $Q_{\mathrm{p}}>0.8$ ) and x - admixed (one populations with intermediate $Q_{\mathrm{p}}$ ). For locality information see Table 1; for individual genotypes see Online Supplementary Information $\mathrm{S} 1$; for $Q$-scores along with NewHybrid results see Figure 3. A. $\mathrm{kml}$ file for visualization with e.g. Google Earth is provided as Online Supplementary Information S2.

\begin{tabular}{|c|c|c|c|}
\hline Population & Structure Q-score & Sample size & Species classification \\
\hline 2 & 0.958 & 20 & $\mathrm{p}$ \\
\hline 3 & 0.949 & 19 & $\mathrm{p}$ \\
\hline 4 & 0.935 & 22 & $\mathrm{p}$ \\
\hline 5 & 0.989 & 17 & $\mathrm{p}$ \\
\hline 7 & 0.026 & 36 & $\mathrm{~m}$ \\
\hline 12 & 0.038 & 10 & $\mathrm{~m}$ \\
\hline 19 & 0.215 & 14 & $\mathrm{x}$ \\
\hline 26 & 0.977 & 22 & $\mathrm{p}$ \\
\hline 29 & 0.988 & 23 & $\mathrm{p}$ \\
\hline 30 & 0.977 & 7 & $\mathrm{p}$ \\
\hline 32 & 0.885 & 10 & $\mathrm{p}$ \\
\hline 42 & 0.036 & 7 & $\mathrm{~m}$ \\
\hline 51 & 0.038 & 25 & $\mathrm{~m}$ \\
\hline 55 & 0.083 & 10 & $\mathrm{~m}$ \\
\hline 58 & 0.054 & 7 & $\mathrm{~m}$ \\
\hline 62 & 0.032 & 5 & $\mathrm{~m}$ \\
\hline 65 & 0.989 & 10 & $\mathrm{p}$ \\
\hline 67 & 0.942 & 34 & $\mathrm{p}$ \\
\hline 70 & 0.017 & 7 & $\mathrm{~m}$ \\
\hline 72 & 0.055 & 10 & $\mathrm{~m}$ \\
\hline 76 & 0.015 & 5 & $\mathrm{~m}$ \\
\hline 80 & 0.037 & 38 & $\mathrm{~m}$ \\
\hline 84 & 0.925 & 41 & $\mathrm{p}$ \\
\hline 87 & 0.990 & 4 & $\mathrm{p}$ \\
\hline 88 & 0.991 & 3 & $\mathrm{p}$ \\
\hline 90 & 0.978 & 27 & $\mathrm{p}$ \\
\hline 91 & 0.081 & 21 & $\mathrm{~m}$ \\
\hline 92 & 0.014 & 25 & $\mathrm{~m}$ \\
\hline 93 & 0.988 & 11 & $\mathrm{p}$ \\
\hline 95 & 0.016 & 21 & $\mathrm{~m}$ \\
\hline 96 & 0.013 & 10 & $\mathrm{~m}$ \\
\hline 97 & 0.970 & 26 & $\mathrm{p}$ \\
\hline 98 & 0.973 & 20 & $\mathrm{p}$ \\
\hline 100 & 0.108 & 24 & $\mathrm{~m}$ \\
\hline 102 & 0.031 & 21 & $\mathrm{~m}$ \\
\hline 103 & 0.033 & 28 & $\mathrm{~m}$ \\
\hline 104 & 0.963 & 22 & $\mathrm{p}$ \\
\hline 107 & 0.840 & 40 & $\mathrm{p}$ \\
\hline 108 & 0.053 & 31 & $\mathrm{~m}$ \\
\hline 119 & 0.008 & 1 & $\mathrm{~m}$ \\
\hline 121 & 0.014 & 2 & $\mathrm{~m}$ \\
\hline 122 & 0.017 & 8 & $\mathrm{~m}$ \\
\hline 127 & 0.980 & 6 & $\mathrm{p}$ \\
\hline 134 & 0.960 & 8 & $\mathrm{p}$ \\
\hline 135 & 0.981 & 7 & $\mathrm{p}$ \\
\hline 136 & 0.982 & 21 & $\mathrm{p}$ \\
\hline 145 & 0.978 & 24 & $\mathrm{p}$ \\
\hline 146 & 0.974 & 2 & $\mathrm{p}$ \\
\hline 147 & 0.982 & 10 & $\mathrm{p}$ \\
\hline 148 & 0.978 & 20 & $\mathrm{p}$ \\
\hline 196 & 0.073 & 14 & $\mathrm{~m}$ \\
\hline 203 & 0.030 & 1 & $\mathrm{~m}$ \\
\hline 217 & 0.024 & 21 & $\mathrm{~m}$ \\
\hline 218 & 0.012 & 4 & $\mathrm{~m}$ \\
\hline 219 & 0.151 & 3 & $\mathrm{~m}$ \\
\hline 222 & 0.983 & 11 & $\mathrm{p}$ \\
\hline
\end{tabular}


Table 3. Frequency of species-indicative haplotypes for three nuclear genes (BF, CALR and PDG) and the mitochondrial ND4 gene, along with sample sizes in brackets and classification results, with $\mathrm{m}-$ Triturus marmoratus (34 populations with $\bar{F}_{\mathrm{p}}<0.20$ ), $\mathrm{p}-T$. pygmaeus (36 populations with $\bar{F}_{\mathrm{p}}>0.8$ ) and $\mathrm{x}$ - admixed (nine populations with $\bar{F}_{\mathrm{p}}$ intermediate). For locality information see Table 1 . A . kml file for visualization with e.g. Google Earth is provided as Online Supplementary Information S3.

\begin{tabular}{|c|c|c|c|c|c|}
\hline Population & $\mathrm{BF}(\mathrm{N})$ & CALR $(\mathrm{N})$ & PDG (N) & ND4 (N) & Classification \\
\hline 2 & $1.00(5)$ & $1.00(5)$ & $0.70(5)$ & $1.00(6)$ & $\mathrm{p}$ \\
\hline 3 & $1.00(1)$ & $1.00(4)$ & $0.50(5)$ & $1.00(5)$ & $\mathrm{p}$ \\
\hline 4 & $0.33(3)$ & $1.00(5)$ & $1.00(6)$ & $0.50(8)$ & $\mathrm{x}$ \\
\hline 7 & & & & $0.00(4)$ & $\mathrm{m}$ \\
\hline 12 & $0.50(2)$ & $0.25(2)$ & $0.00(2)$ & $0.00(5)$ & $\mathrm{m}$ \\
\hline 19 & & & & $0.00(5)$ & $\mathrm{m}$ \\
\hline 26 & & $1.00(3)$ & & $1.00(5)$ & $\mathrm{p}$ \\
\hline 28 & $1.00(5)$ & $1.00(5)$ & $0.50(5)$ & $1.00(5)$ & $\mathrm{p}$ \\
\hline 30 & $1.00(4)$ & $1.00(5)$ & $1.00(4)$ & $0.75(4)$ & $\mathrm{p}$ \\
\hline 32 & $0.00(4)$ & & & $0.00(5)$ & $\mathrm{m}$ \\
\hline 38 & & $0.00(4)$ & & & $\mathrm{m}$ \\
\hline 39 & & & & $1.00(4)$ & $\mathrm{p}$ \\
\hline 42 & $0.10(5)$ & $0.13(4)$ & $0.38(4)$ & $0.00(5)$ & $\mathrm{m}$ \\
\hline 51 & $0.50(4)$ & $0.00(5)$ & $0.00(7)$ & $0.20(5)$ & $\mathrm{m}$ \\
\hline 55 & $0.25(4)$ & $0.20(5)$ & $0.50(5)$ & $0.40(5)$ & $\mathrm{x}$ \\
\hline 58 & & & & $0.60(5)$ & $\mathrm{x}$ \\
\hline 62 & & & & $0.00(3)$ & $\mathrm{m}$ \\
\hline 64 & & & & $0.00(5)$ & $\mathrm{m}$ \\
\hline 65 & $0.67(3)$ & $1.00(7)$ & $0.90(5)$ & $1.00(5)$ & $\mathrm{p}$ \\
\hline 66 & $1.00(1)$ & $1.00(1)$ & $1.00(1)$ & $0.75(4)$ & $\mathrm{p}$ \\
\hline 67 & $1.00(5)$ & $1.00(5)$ & $0.60(5)$ & $1.00(5)$ & $\mathrm{p}$ \\
\hline 69 & & & & $0.00(10)$ & $\mathrm{m}$ \\
\hline 70 & & & & $0.00(3)$ & $\mathrm{m}$ \\
\hline 72 & & & & $0.00(3)$ & $\mathrm{m}$ \\
\hline 76 & $0.00(5)$ & $0.13(4)$ & $0.00(5)$ & $0.00(5)$ & $\mathrm{m}$ \\
\hline 80 & $0.20(5)$ & $0.20(5)$ & $0.00(5)$ & $0.00(4)$ & $\mathrm{m}$ \\
\hline 81 & $1.00(4)$ & $1.00(5)$ & $0.50(9)$ & $0.80(5)$ & $\mathrm{x}$ \\
\hline 84 & $1.00(2)$ & $1.00(3)$ & $0.75(4)$ & $0.50(4)$ & $\mathrm{x}$ \\
\hline 87 & & & & $1.00(3)$ & $\mathrm{p}$ \\
\hline 88 & $1.00(1)$ & $1.00(1)$ & $1.00(1)$ & $1.00(2)$ & $\mathrm{p}$ \\
\hline 90 & $1.00(7)$ & $1.00(9)$ & $1.00(10)$ & $0.63(8)$ & $\mathrm{p}$ \\
\hline 91 & $0.33(3)$ & 0.00 (3) & $0.00(5)$ & $0.00(5)$ & $\mathrm{m}$ \\
\hline 92 & $0.30(5)$ & $0.00(5)$ & $0.00(5)$ & $0.00(5)$ & $\mathrm{m}$ \\
\hline 93 & $1.00(5)$ & $1.00(4)$ & $1.00(4)$ & $1.00(5)$ & $\mathrm{p}$ \\
\hline 94 & $1.00(5)$ & $1.00(5)$ & $1.00(5)$ & $1.00(5)$ & $\mathrm{p}$ \\
\hline 95 & & & & $0.00(5)$ & $\mathrm{m}$ \\
\hline 96 & $0.38(4)$ & $0.00(5)$ & $0.00(4)$ & $0.00(5)$ & $\mathrm{m}$ \\
\hline 97 & & & & $1.00(3)$ & $\mathrm{p}$ \\
\hline 98 & & & & $1.00(4)$ & $\mathrm{p}$ \\
\hline 99 & $1.00(10)$ & $1.00(10)$ & $0.30(10)$ & $1.00(10)$ & $\mathrm{p}$ \\
\hline 100 & & & & $0.00(5)$ & $\mathrm{m}$ \\
\hline 102 & $0.10(5)$ & $0.00(5)$ & $0.00(5)$ & $0.00(5)$ & $\mathrm{m}$ \\
\hline 103 & $0.00(1)$ & $0.00(4)$ & $0.00(5)$ & $0.00(5)$ & $\mathrm{m}$ \\
\hline 104 & $1.00(5)$ & $1.00(5)$ & $0.75(2)$ & $1.00(5)$ & $\mathrm{p}$ \\
\hline 105 & $0.00(5)$ & $0.00(5)$ & $0.20(5)$ & $0.00(5)$ & $\mathrm{m}$ \\
\hline 106 & $0.20(5)$ & $0.00(5)$ & $0.60(5)$ & $0.00(5)$ & $\mathrm{x}$ \\
\hline
\end{tabular}


Table 3 continued

\begin{tabular}{|c|c|c|c|c|c|}
\hline Population & $\mathrm{BF}(\mathrm{N})$ & CALR (N) & PDG (N) & ND4 (N) & Classification \\
\hline 107 & $0.67(3)$ & $0.33(3)$ & $0.75(4)$ & $0.25(4)$ & $\mathrm{x}$ \\
\hline 108 & & & & $0.00(5)$ & $\mathrm{m}$ \\
\hline 109 & $0.00(5)$ & $0.10(5)$ & $0.30(5)$ & $0.00(5)$ & $\mathrm{m}$ \\
\hline 110 & $1.00(5)$ & $1.00(5)$ & $0.80(5)$ & $0.80(5)$ & $\mathrm{p}$ \\
\hline 114 & $0.00(2)$ & 0.17 (3) & $0.00(3)$ & $0.00(3)$ & $\mathrm{m}$ \\
\hline 116 & $0.30(5)$ & $0.00(5)$ & $0.00(5)$ & $0.00(5)$ & $\mathrm{m}$ \\
\hline 127 & $1.00(4)$ & $1.00(4)$ & $0.50(4)$ & & $\mathrm{p}$ \\
\hline 134 & $1.00(4)$ & $1.00(4)$ & $0.75(4)$ & $1.00(4)$ & $\mathrm{p}$ \\
\hline 135 & $1.00(3)$ & $1.00(4)$ & $0.50(4)$ & $1.00(5)$ & $\mathrm{p}$ \\
\hline 136 & $1.00(5)$ & $1.00(5)$ & $0.70(5)$ & $1.00(5)$ & $\mathrm{p}$ \\
\hline 138 & $0.00(2)$ & $1.00(1)$ & $0.50(1)$ & $0.00(3)$ & $\mathrm{x}$ \\
\hline 139 & $1.00(1)$ & $1.00(1)$ & $1.00(1)$ & $1.00(4)$ & $\mathrm{p}$ \\
\hline 141 & $0.00(2)$ & $0.00(3)$ & $0.00(1)$ & $0.00(4)$ & $\mathrm{m}$ \\
\hline 145 & $1.00(4)$ & $1.00(5)$ & $1.00(5)$ & $1.00(5)$ & $\mathrm{p}$ \\
\hline 146 & $1.00(1)$ & $1.00(1)$ & $1.00(1)$ & $1.00(1)$ & $\mathrm{p}$ \\
\hline 147 & $1.00(2)$ & $1.00(3)$ & $0.50(4)$ & $1.00(4)$ & $\mathrm{p}$ \\
\hline 148 & $1.00(5)$ & $1.00(5)$ & $0.90(5)$ & $1.00(5)$ & $\mathrm{p}$ \\
\hline 196 & $0.00(5)$ & $0.00(5)$ & $0.00(5)$ & $0.00(5)$ & $\mathrm{m}$ \\
\hline 205 & $1.00(5)$ & $1.00(5)$ & $0.70(5)$ & $1.00(5)$ & $\mathrm{p}$ \\
\hline 208 & $1.00(4)$ & $1.00(3)$ & $0.50(1)$ & $1.00(2)$ & $\mathrm{p}$ \\
\hline 209 & $1.00(4)$ & $0.90(5)$ & $0.40(5)$ & $1.00(4)$ & $\mathrm{p}$ \\
\hline 217 & $0.00(5)$ & $0.00(5)$ & $0.00(5)$ & $0.00(5)$ & $\mathrm{m}$ \\
\hline 218 & $0.00(4)$ & $0.00(4)$ & $0.00(4)$ & $0.25(4)$ & $\mathrm{m}$ \\
\hline 219 & $1.00(1)$ & $0.00(1)$ & $0.00(1)$ & $0.00(1)$ & $\mathrm{x}$ \\
\hline 222 & $1.00(5)$ & $1.00(5)$ & $0.70(5)$ & $0.80(5)$ & $\mathrm{p}$ \\
\hline 224 & $0.00(3)$ & $0.00(4)$ & $0.25(4)$ & $0.25(4)$ & $\mathrm{m}$ \\
\hline 273 & $1.00(4)$ & & $1.00(4)$ & $1.00(3)$ & $\mathrm{p}$ \\
\hline 336 & & 0.00 (1) & $0.00(1)$ & & $\mathrm{m}$ \\
\hline 337 & & $0.00(3)$ & $0.00(4)$ & & $\mathrm{m}$ \\
\hline 338 & $1.00(4)$ & & $1.00(5)$ & & $\mathrm{p}$ \\
\hline 339 & $1.00(1)$ & $0.00(3)$ & $0.00(3)$ & & $\mathrm{m}$ \\
\hline 340 & $1.00(3)$ & & $1.00(3)$ & $1.00(3)$ & $\mathrm{p}$ \\
\hline 341 & & & $1.00(3)$ & $1.00(3)$ & $\mathrm{p}$ \\
\hline
\end{tabular}

in the north and T. pygmaeus in the south of the Iberian peninsula. The transition between the species is sharp. The admixed populations are located at the species contact area in central Portugal $(\mathrm{N}=6)$, eastern Portugal $(\mathrm{N}=2)$ and western Spain $(\mathrm{N}=2$, Figure 4; for details see Online Supplementary Information S2 and S3). Notable is the northerly distribution of $T$. pygmaeus along the Atlantic coast and the isolated occurrence of $T$. marmoratus directly north of the Lisbon peninsula. Because these results closely follow earlier reconstructions (e.g. Arntzen and Espregueira Themudo, 2008) and link up to the species borders recorded for Spain (García-París et al., 1993; 2001; Pleguezuelos et al., 2002) the results set the scene for an evaluation of the performance of morphological data for species identification.

The replicated morphology measures were analyzed by principal component (PC) analysis. The first and second axes explained $28.1 \%$ and $18.8 \%$ of the total explained variance, respectively. The analysis revealed correspondence among three data sets out of four (Figure 5), suggesting that one observer measured in a different manner than the others. The outlying data shifted along the second PC-axis that has particularly high loadings for digit lengths (TFl and FTl) and the characters describing the extent of the black ventral colouration. The mean coefficient of variation $(V)$ per character for the three 
Table 4. Performance of morphological characters for Triturus marmoratus - T. pygmaeus species identification in stepwise discriminant analysis and univariate $t$-tests. Model fit is expressed by the 'area under the curve' (AUC) statistic. For character descriptions and abbreviations see text. Also shown are species characteristics and the coefficient of variation obtained from replicated measurements (see Figure 5).

\begin{tabular}{|c|c|c|c|c|c|c|c|c|}
\hline \multirow[t]{2}{*}{ Character } & \multirow{2}{*}{$\begin{array}{l}\text { Unit, } \\
\text { transformation \& }\end{array}$} & \multicolumn{2}{|c|}{ Order of selection \# } & \multicolumn{2}{|c|}{ Model fit } & \multicolumn{2}{|c|}{$\begin{array}{c}\text { Species with higher } \\
\text { value } \$\end{array}$} & \multirow{2}{*}{$\begin{array}{c}\text { Mean } \\
\text { coefficient } \\
\text { of variation } \\
(\% \mathrm{~V}) \\
\end{array}$} \\
\hline & & Males & Females & Males & Females & Males & Females & \\
\hline \multicolumn{9}{|c|}{ Size variable } \\
\hline SV1 & $\mathrm{mm}, \ln$ & 1 & 2 & 0.931 & 0.891 & $\mathrm{~m}$ & $\mathrm{~m}$ & 0.98 \\
\hline \multicolumn{9}{|c|}{ Shape variables } \\
\hline $\mathrm{Hl}$ & $\mathrm{mm}$, lnstres & & & 0.532 & 0.501 & & & 7.4 \\
\hline $\mathrm{Hw}$ & $\mathrm{mm}$, lnstres & 3 & 4 & 0.708 & 0.639 & $\mathrm{~m}$ & $\mathrm{~m}$ & 2.5 \\
\hline ILd & $\mathrm{mm}$, lnstres & 8 & 5 & 0.500 & 0.628 & & $\mathrm{p}$ & 3.4 \\
\hline $\mathrm{FLl}$ & $\mathrm{mm}$, lnstres & & 6 & 0.687 & 0.742 & $\mathrm{~m}$ & $\mathrm{~m}$ & 2.7 \\
\hline $\mathrm{TFl}$ & $\mathrm{mm}$, lnstres & 4 & & 0.687 & 0.589 & $\mathrm{~m}$ & $\mathrm{~m}$ & 6.6 \\
\hline HLl & $\mathrm{mm}$, lnstres & & & 0.640 & 0.648 & $\mathrm{~m}$ & $\mathrm{~m}$ & 3.1 \\
\hline FTl & $\mathrm{mm}$, lnstres & & & 0.600 & 0.503 & $\mathrm{~m}$ & & 9.2 \\
\hline \multicolumn{9}{|c|}{ Ventral colouration characteristics } \\
\hline $\mathrm{Bc}$ & Scale $1-5$ & 5 & 3 & 0.728 & 0.719 & $\mathrm{~m}$ & $\mathrm{~m}$ & 16.9 \\
\hline WSn & Scale $1-5$ & 9 & & 0.556 & 0.520 & $\mathrm{~m}$ & & 12.4 \\
\hline WSs & Scale $1-4$ & & & 0.645 & 0.605 & $\mathrm{~m}$ & $\mathrm{~m}$ & 26.9 \\
\hline $\mathrm{BSn}$ & Scale 1-5 & 6 & 8 & 0.505 & 0.514 & & $\mathrm{p}$ & 15.6 \\
\hline BSs & Scale $1-4$ & 7 & 9 & 0.648 & 0.515 & $\mathrm{~m}$ & & 11.4 \\
\hline \multicolumn{9}{|c|}{ Dorso-lateral colouration characteristics } \\
\hline Links & Count & 2 & 1 & 0.914 & 0.935 & $\mathrm{p}$ & $\mathrm{p}$ & 6.4 \\
\hline Toplinks & Count & & 7 & 0.704 & 0.693 & $\mathrm{~m}$ & $\mathrm{~m}$ & 24.3 \\
\hline \multicolumn{4}{|c|}{ Characters selected in stepwise disciminant analysis } & 0.990 & 0.981 & & & \\
\hline \multicolumn{4}{|c|}{$\underline{\text { SVl and Links }}$} & 0.976 & 0.966 & & & \\
\hline
\end{tabular}

$\&$ lnstres - standardized residuals of the regression of ln 'character' on ln SVL

\# in stepwise discriminant analysis

$\$$ significant in univariate t-test; $\mathrm{m}$ - T. marmoratus, $\mathrm{p}-$ T. pygmaeus

coinciding data sets is low for the character SVl $(V<$ $0.01)$, moderate for Hw, ILd, FLl and HLl $(0.01<V$ $<0.04)$, substantial for $\mathrm{Hl}, \mathrm{TFl}, \mathrm{FTl}$ and Links $(0.04<$ $V<0.10)$ and large for the six remaining colouration characteristics $(V>0.10$, Table 4$)$.

The morphometric data show that T. marmoratus is the larger species (Table 4). It has a wider head and longer extremities than T.pygmaeus. Interlimb distance is relatively larger in T.pygmaeus than in T.marmoratus, but the difference is only statistically significant for females. Scores for the ventral colouration characters are generally higher for $T$. marmoratus than for $T$. pygmaeus, pointing to darker and lighter colourations, respectively. Scores for Links are higher in T. pygmaeus and scores for Toplinks are higher in T. marmoratus. $\mathrm{SVl}$ and Links are the prime characters selected in the discriminant analysis. These characters stand out for efficient species discrimination to the extent that model fit on the basis of these two characters $(0.97<$ AUC < 0.98) is only marginally less than for the set of nine characters selected by discriminant analysis $(0.98<$ AUC $<0.99$, Table 4). In two populations out of 59, species frequencies from enzyme genetic and morphological characters are significantly different ( $G$-test for independence, $P<0.05$ for population 3, and $P<0.001$ for population 80). These populations are located at or close to $(<20 \mathrm{~km})$ the centre of the hybrid zone (see Table 1 and Figure 4). 


\section{Second PC-axis}

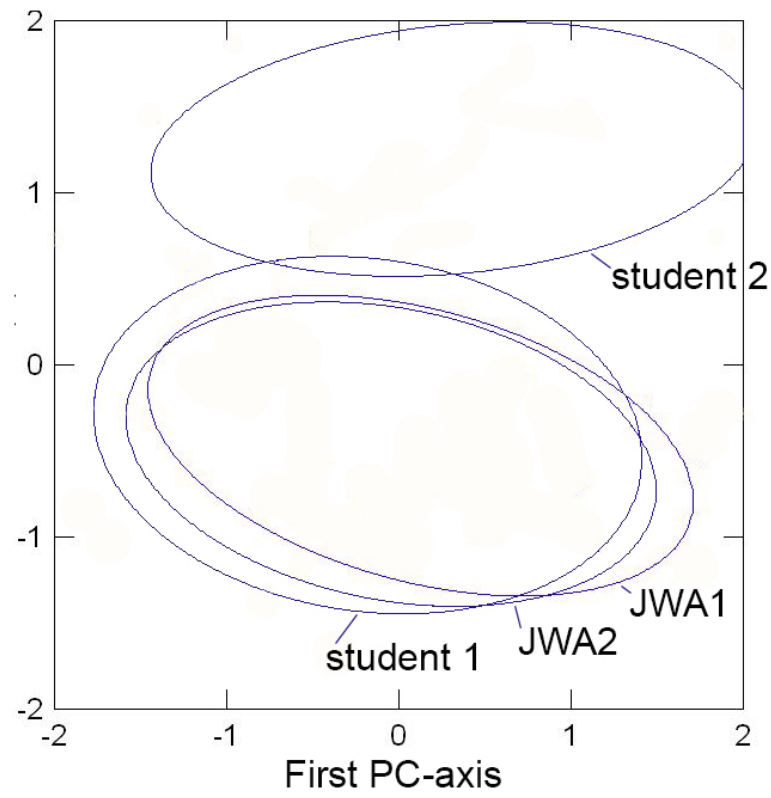

Figure 5. Analysis of replicated morphological measurement on 21 marbled newts (seven males and 14 females from population 91) by principal component analysis. Ellipses indicate one standard deviation of the mean. The results for 'student 2' differ from the others along the second PC-axis and mainly concern the measurements of digits (TFl, FTl) and the scores on the black ventral colouration (BSn, BSs).

The morphological identification criteria were also applied to populations for which enzyme data were unavailable. The species distributions on the basis of external morphology closely follows that of the molecules (Figure 4). However, in the contour plot of discriminant species probabilities, the transition zone is wide, in particular north of the Lisbon peninsula where the species distribution forms a mosaic. Along the coast the species transition zone reaches up to Aveiro. In central Portugal it follows the Tejo river and runs through the town Idanha-a-Nova into Spain where it follows the northern edge of Extremadura and, presumably, the southern edge of Castile and León, and into the province of Madrid where the species contact discontinues. Digital deformities I observed in 19 individuals in ten populations, located inside as well as outside the species transition zone (Table 1).

At the transect the T. marmoratus $-T$. pygmaeus species transition is sharp and coincides with the position of the Tejo river, for most characters studied (Table 5, Figures 6 and 7). With the pooled enzyme genetic data set as a reference, the clines are congruent, with the exception of female SVl and $P D G$ for which clines are marginally wider than the reference cline. The cline for mtDNA stands out on the basis of its width and southerly position. For the characters lnSVl and Links the clines revealed a prevalence of intermediate values at the very centre of the contact zone (Figure 6CDE). This raised the question if these morphologically intermediate populations were composed of genetically admixed individuals. Because the sample in the transect was small, I performed analyses with all data, with the $Q$-scores classification as above, and with admixture set as a wider class $(0.1<Q<0.9)$. An ANOVA indicated significant differences for the three groups, with the genetically admixed group as morphologically intermediate (Table 6).

\section{Discussion}

I reconstructed the distribution of the hybridizing newt species $T$. marmoratus and $T$. pygmaeus over the western part of the Iberian Peninsula from morphological and molecular data. I report on ten admixed populations that all are located at the $T$. marmoratus - T. pygmaeus range interface. Yet, the molecular data show a strong bimodality with few admixed individuals, suggesting that interspecific hybridization is limited, possibly with strong selection against hybrids (Barton and Hewitt, 1985; Mallet, 2005). The level of hybridization is comparable to that in Triturus crested newts at the same level of divergence (Arntzen et al., 2014). Some introgression appears to have taken place as shown by admixed individuals in e.g. populations 100, 104 and 107 (Figure 3). However, with few partially diagnostic markers 'admixed' genotypes may have arisen by chance recombination. This may be the case in population 100 that is located away from the species contact zone and figures as an outlier in cline analysis (Figure 6F). Morphologically intermediate individuals are more numerous than genetically admixed individuals, suggesting that the molecular markers do not reflect the full scope of $T$. marmoratus x $T$. pygmaeus hybridization. To document introgression and to elucidate hybrid zone structure at a fine scale, more genetic markers are required.

Morphological characters that stand out for species identification are body size (SVl) and the dorso-lateral 
Table 5. Parameter estimates for the maximum-likelihood geographical clines for morphological data (top panel), nuclear genetic data (middle panel) and nuclear and mitochondrial sequence data (bottom panel) over the south to north transect shown in Figure 4. Cline position is relative to Tejo river at $8^{\circ} \mathrm{W}$ and width is 1 /maximum slope. Confidence intervals are based upon the $2 \log$-likelihood unit support limits. $\delta$ and $\tau$ are the shape parameters for the tails, with fitting at a mirror $(\mathrm{M})$, at the right $(\mathrm{R})$ or none $(\mathrm{N})$. The parameters $P_{\min }$ and $P_{\max }$ are the estimated values at either end of the transect and are set to minimum and maximum values (typ models), fixed to their empirical values (fix models), or $P_{\min }$ and $P_{\max }$ are fitted (opt models). Clines are shown in Figures 6 and 7.

\begin{tabular}{|c|c|c|c|c|c|c|c|c|c|c|c|c|c|c|}
\hline \multirow[t]{2}{*}{ Character } & \multirow[t]{2}{*}{ Model } & \multirow{2}{*}{$\begin{array}{l}\text { Position } \\
(\mathrm{km}) \#\end{array}$} & \multicolumn{2}{|c|}{$\begin{array}{l}\text { Confidence } \\
\text { interval }\end{array}$} & \multirow{2}{*}{$\begin{array}{l}\text { Width } \\
(\mathrm{km})\end{array}$} & \multicolumn{2}{|c|}{$\begin{array}{l}\text { Confidence } \\
\text { interval }\end{array}$} & \multicolumn{2}{|c|}{ Mirror } & \multicolumn{2}{|c|}{ Right } & \multicolumn{2}{|c|}{$\mathrm{P}$} & \multirow{2}{*}{$\begin{array}{l}\text { Cline } \\
\text { shown } \\
\text { in Figure }\end{array}$} \\
\hline & & & Min & Max & & Min & Max & $\delta$ & $\tau$ & $\delta$ & $\tau$ & Min & Max & \\
\hline \multicolumn{15}{|c|}{ Morphological data analysed with stepwise discriminant analysis - 31 populations } \\
\hline All populations & OptR & 0.73 & -0.09 & 1.65 & 1.17 & 0.12 & 2.81 & & & 0.387 & 0.031 & 0.017 & 0.985 & \\
\hline $\begin{array}{l}\text { Populations with } \\
\text { genetic data }\end{array}$ & OptR & 2.15 & 0.83 & 3.05 & 4.75 & 1.83 & 4.91 & & & 1.683 & 0.140 & 0.018 & 0.991 & $6 \mathrm{~A}$ \\
\hline $\begin{array}{l}\text { Populations without } \\
\text { genetic data }\end{array}$ & OptN & 1.25 & -1.07 & 1.91 & 0.23 & 0.00 & 2.73 & & & & & 0.119 & 0.979 & $6 \mathrm{~B}$ \\
\hline \multicolumn{15}{|c|}{ Morphology, single characters - 29 populations } \\
\hline lnSVl, males & OptN & 0.07 & -24.47 & 5.03 & 16.54 & 0.28 & 109.92 & & & & & 4.028 & 4.263 & $6 \mathrm{C}$ \\
\hline $\operatorname{lnSVl}$, females & OptN & 0.53 & -11.64 & 6.00 & 14.65 & 5.60 & 86.51 & & & & & 4.055 & 4.299 & $6 \mathrm{D}$ \\
\hline Links & OptN & 1.68 & -0.15 & 1.85 & 0.49 & 0.02 & 2.22 & & & & & 1.718 & 8.650 & $6 \mathrm{E}$ \\
\hline \multicolumn{15}{|c|}{ Nuclear genetic data analysed with Structure - 14 populations } \\
\hline Four loci & FixM & 2.14 & 0.14 & 3.47 & 1.23 & 0.15 & 5.21 & 0.759 & 0.009 & & & 0.024 & 0.988 & $6 \mathrm{~F}$ \\
\hline PepA & TypM & 1.24 & 0.25 & 3.42 & 1.80 & 0.20 & 8.63 & 0.727 & 0.003 & & & 0 & 1 & $6 \mathrm{G}$ \\
\hline РepB & OptN & -1.17 & -4.20 & 0.23 & 5.01 & 1.42 & 13.02 & & & & & 0.067 & 0.789 & $6 \mathrm{H}$ \\
\hline PepD & OptN & 0.77 & -0.20 & 3.82 & 1.39 & 0.00 & 5.23 & & & & & 0.155 & 0.786 & $6 \mathrm{~J}$ \\
\hline Ldh2 & FixN & 26.72 & -124 & $>125$ & $>400$ & 4.54 & $>>400$ & & & & & 0.079 & 0.869 & $6 \mathrm{~K}$ \\
\hline \multicolumn{15}{|c|}{ DNA sequence data, analyzed from species indicative haplotype frequencies - eight populations } \\
\hline $\mathrm{BF}$ & OptN & -7.49 & -57.62 & 2.67 & 18.63 & 0.002 & 106.71 & & & & & 0.180 & 0.997 & $7 \mathrm{~L}$ \\
\hline CALR & TypN & 3.23 & -0.49 & 7.29 & 7.53 & 2.91 & 34.15 & & & & & 0 & 1 & $7 \mathrm{M}$ \\
\hline PDG & TypN & 5.99 & 1.73 & 19.47 & 12.21 & 5.34 & 81.86 & & & & & 0 & 1 & $7 \mathrm{~N}$ \\
\hline ND4 mitochondrial & TypR & -19.28 & -51.29 & -5.54 & 78.86 & 26.24 & 182.44 & & & 51.88 & & 0 & 1 & $7 \mathrm{P}$ \\
\hline
\end{tabular}

\# Relative to the Tejo river at $8.0^{\circ} \mathrm{W}$. Note that the transect crosses the Tejo river at an angle, at positions varying from $39.446^{\circ}$ to $39.543^{\circ} \mathrm{N}$, amounting to a latitudinal difference of $10.8 \mathrm{~km}$.

colour pattern (Links). Marbled newts with SVl $>63$ (males), $\mathrm{SVl}>65$ (females) and Links $\leq 5$ are likely to be T. marmoratus, whereas marbled newts smaller than that with higher link counts are likely to be $T$. pygmaeus. Triturus pygmaeus was described as a small sized ('pygmy') subspecies of T. marmoratus by Wolterstorff (1905) with Algeciras, Cadiz as type locality. Body size was considered a diagnostic character on the basis of material from the same region (García-París et al., 1993). However, southern populations of $T$. pygmaeus may be of particular small body size (Diaz-Paniagua et al., 1996). Body size may also be affected by local feeding conditions and other environmental variables. Moreover, newts show indeterminate growth (Arntzen, 2000) so that individual age is a confounding factor. The character Links has higher diagnostic power than body size and is equally applicable to males and females. However, diagnostic power appears to break down in the very south of Spain where link counts for T. pygmaeus are close to zero (García-París et al., 1993). Observer bias may be an issue in morphological species identification, but was not shown to affect SVl or Links. Counting links may be ambiguous if there are many, but with a threshold set at 5.5 this is not an identification issue. Marbled newts with aberrant colour patterns were found at the hybrid zone. In some ways similar 'reticulate' or 'wavy' colouration patterns have been observed in Bombina bombina (Linnaeus, 1761) x B. variegata (Linnaeus, 1758) reciprocal crosses (Héron-Royer, 1891; Michalowski and Madej, 1969). Given the observations of toe abnormalities well outside the hybrid zone it is unclear if these have to do with hybridization, as was 
Table 6. Analysis of variance on morphological characters selected for species discrimination, applied to the groups Triturus marmoratus (1), admixed (2) and T. pygmaeus (3).

\begin{tabular}{|c|c|c|c|c|c|c|c|c|}
\hline \multirow[t]{3}{*}{ Genetically classified groups } & \multirow{3}{*}{$\begin{array}{c}\text { Sample } \\
\text { size }\end{array}$} & \multicolumn{3}{|c|}{ Mean character values \# } & \multicolumn{4}{|c|}{ Significance in Tamhane's T2 post-hoc test } \\
\hline & & \multicolumn{2}{|c|}{$\mathrm{SVl}(\mathrm{mm})$} & \multirow{2}{*}{$\begin{array}{l}\text { Links } \\
\text { number }\end{array}$} & \multirow{2}{*}{$\begin{array}{c}\text { Groups } \\
\text { compared }\end{array}$} & \multicolumn{2}{|c|}{ SV1 } & \multirow[b]{2}{*}{ Links } \\
\hline & & Males & Females & & & Males & Females & \\
\hline \multicolumn{9}{|l|}{ Intermediate group small } \\
\hline 1 - T. marmoratus $\left(Q_{\mathrm{p}}<0.2\right)$ & 393 & 69.1 & 71.8 & 1.49 & 12 & NS & NS & $* * *$ \\
\hline 2 - admixed $\left(0.2<Q_{\mathrm{p}}<0.8\right)$ & 35 & 62.6 & 66.8 & 6.29 & 23 & NS & NS & NS \\
\hline $3-T . p y g m a e u s\left(Q_{\mathrm{p}}>0.8\right)$ & 466 & 58.2 & 62.9 & 7.97 & 13 & $* * *$ & $* * *$ & $* * *$ \\
\hline Analysis of variance, F-value & & $\begin{array}{r}453.5 \\
* * *\end{array}$ & $\begin{array}{r}194.6 \\
* * *\end{array}$ & $\begin{array}{r}150.9 \\
* * *\end{array}$ & & & & \\
\hline \multicolumn{9}{|l|}{ Intermediate group large } \\
\hline 1 - T. marmoratus $\left(Q_{\mathrm{p}}<0.1\right)$ & 361 & 68.8 & 71.8 & 1.43 & 12 & $* * *$ & $* *$ & $* * *$ \\
\hline 2 - admixed $\left(0.1<Q_{\mathrm{p}}<0.9\right)$ & 80 & 62.9 & 67.7 & 5.61 & 23 & $* *$ & $* * *$ & $* * *$ \\
\hline 3 - T.pygmaeus $\left(Q_{\mathrm{p}}>0.9\right)$ & 449 & 58.3 & 62.8 & 7.90 & 13 & $* * *$ & $* * *$ & $* * *$ \\
\hline \multirow[t]{2}{*}{ Analysis of variance, F-value } & & 409.4 & 171.3 & 144.6 & & & & \\
\hline & & $* * *$ & $* * *$ & $* * *$ & & & & \\
\hline
\end{tabular}

NS - not significant, $* *-P<0.01$ and $* * *-P<0.001$

\# To reduce the skewness of the character state distributions to marginally significant levels the data were transformed following the Box Cox procedure

inferred for $T$. cristatus x T. marmoratus hybrids in France (Arntzen and Wallis, 1991).

The clines reconstructed for the transect in central Portugal are largely coincident (located at the same place) and congruent (of the same shape). Hybrid zones are frequently located in areas where populations are sparse and dispersal is impeded (i.e., 'density troughs', Barton and Hewitt, 1985), as may be the case here by the Tejo river. However, the course of the river is not exactly perpendicular to the transect and a more detailed survey over two spatial dimensions is in order to evaluate hybrid zone position as determined by the environment. The different profile of the mtDNA cline (Figure 7P) versus all other, nuclear markers is remarkable. With the knowledge that $T$. pygmaeus has been enlarging its range at the expense of $T$. marmoratus in the nearby coastal area of Portugal (Espregueira Themudo and Arntzen, 2007b) the most straightforward explanation is that $T$. marmoratus had a wider range in central Portugal too, was superseded by $T$. pygmaeus, but not without introgressive hybridization taking place (i.e. hybrid zone movement; Buggs, 2007). Seen like this, the southern mtDNA constitutes a 'genetic footprint' left behind by the receding species $T$. marmoratus.
Modelling has shown that even limited hybridization can result in substantial introgression, when one species is competitively displacing the other (Currat et al, 2008). This genetic footprint is reflected in the cline by an increased width and a displaced, southern position. Mitochondrial DNA is more than nuclear loci prone to chance introgression due to its small effective population size and it is more prone to detection because it stays intact, due to its non-recombining nature (Toews and Brelsford, 2012). The hypothesis of hybrid zone movement can be tested by surveying a larger number of nDNA markers and search for further 'genomic footprints of hybrid zone movement' (Wielstra et al., 2017).

Marbled newt populations are infrequent in the Madrid area (García-París et al., 1989; MartínezSolano, 2006). The two populations studied by Arntzen et al. (2014) are ca. $20 \mathrm{~km}$ apart, with no evidence for hybridization. It may here concern a residual hybrid zone with past but no present opportunities for hybridization and gene flow. Both species appear to suffer from regressing ranges in the east of the Iberian peninsula, as suggested by the isolated occurrences around Barcelona (T. marmoratus) and in Albacete province ( $T$. pygmaeus). The southern fringe of 
Morphology

$P_{\mathrm{DAp}}$, discriminant analysis, populations with genetic data

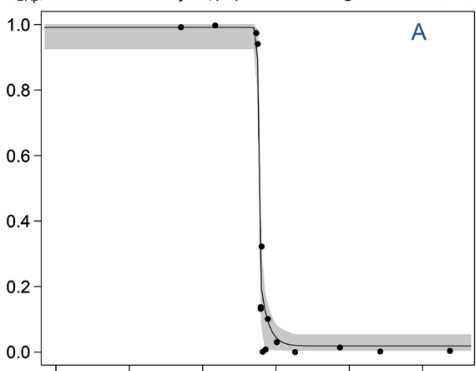

$P_{\mathrm{DAp}}$, discriminant analysis, populations without genetic data

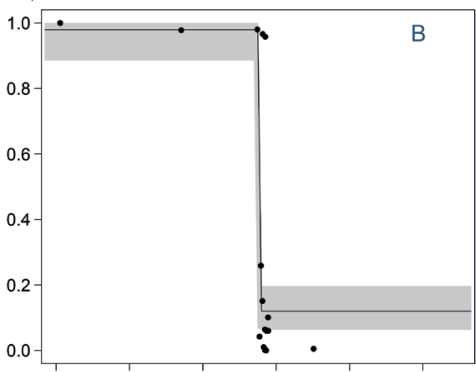

InSVI - males

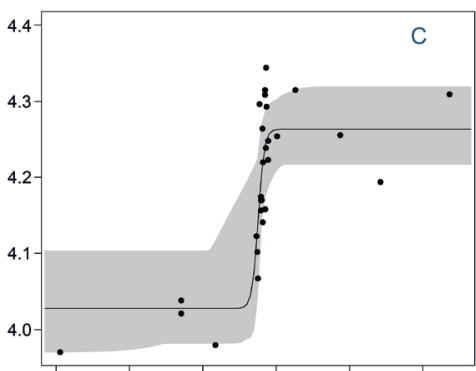

InSVI - females
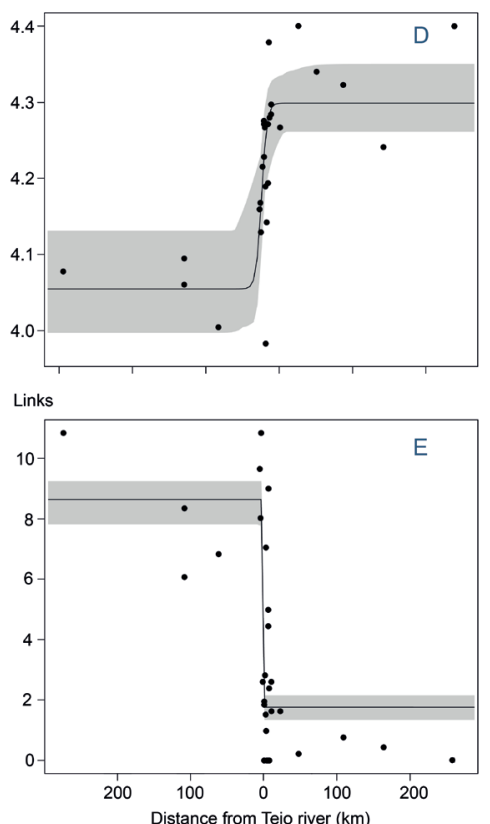

Molecular
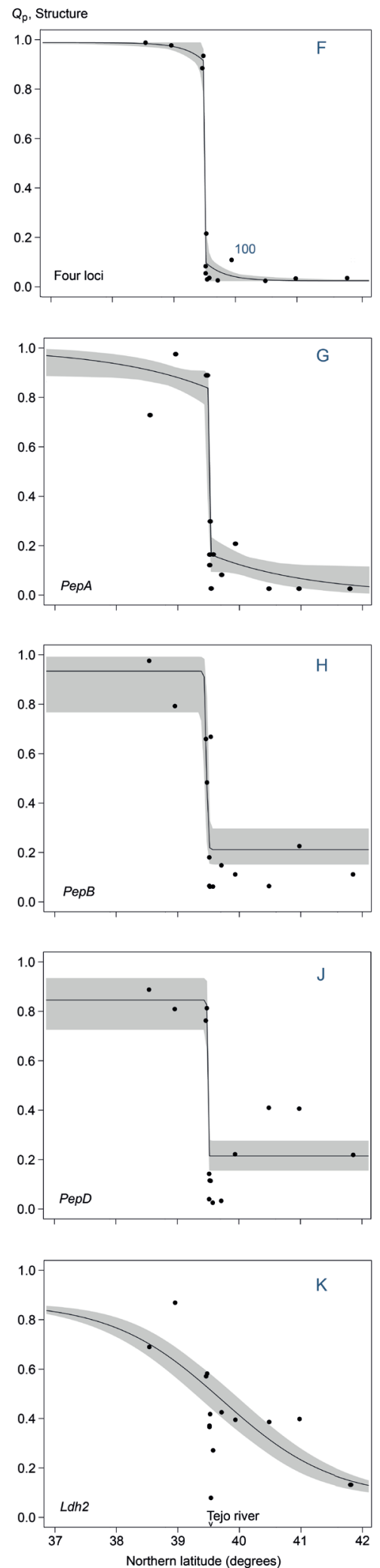

Figure 6. Geographical clines for morphological (left, panels A-E) and nuclear genetic data (right, F-H, K). Solid dots represent populations and the grey areas the $95 \%$ credibility interval. The parameters for formal cline descriptions are in Table 5. Note that the character transitions are mostly steep and located at the Tejo river. Clines are mostly coincident and congruent. The combination of characters (panels A, B and F) outperforms single characters (C-E and G, $\mathrm{H}, \mathrm{J}, \mathrm{K})$ for species classification purposes. Morphological data - discriminant analysis (cf. Table 4) separates the species adequately, for individuals with species identity known (panel A), or unknown from genetic data (B). Note that in B the credibility interval is wider than in $\mathrm{A}$ and the $P_{\min }$ and $P_{\max }$ values are less differentiated. The character Links (panel E) outperforms SVl (C and D) in species diagnostics. In panels $\mathrm{C}$ and D note the preponderance of populations with intermediate SVl at the center of the transect, further analyzed in Table 6. Nuclear genetic data - the loci $P e p A$ and $P e p B$ outperform $L d h 2$, as they do in western Portugal (Espregueira Themudo and Arntzen, 2007). The locus PepD has a performance at par with $P e p A$ and $P e p B$ and accordingly discriminates species better in central than in western Portugal (see $x$ values reported in Espregueira Themudo and Arntzen, 2007a). Population 100 is an outlier for the molecular data (panel F, see also Figure 3). 

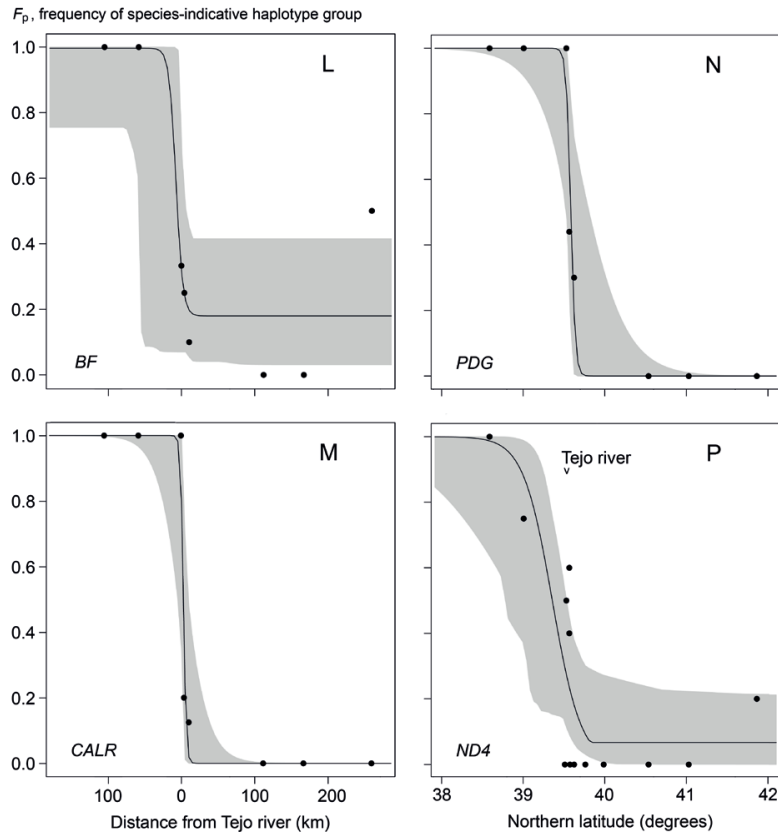

Castile and León remains to be studied. In the north of Extremadura the species contact is located at the lower altitudes of the Sierra de los Ángeles (south of Sierra de Gata), with T.pygmaeus at lower and T. marmoratus at higher altitudes. No obvious ecological correlate for hybrid zone position was found in eastern Portugal. I suggested that $T$. marmoratus and T. pygmaeus engage in a tension hybrid zone (sensu Barton and Hewitt, 1985) that locally follows the minimum spanning distance between fixed points at either side, these flanking positions being the Sierra de Gata in the east and the Tejo river in the west (Arntzen and Espregueira Themudo, 2008). The Tejo river as an approximate species border is followed over a length of at least $20 \mathrm{~km}$. In the west of Portugal T. marmoratus and T. pygmaeus show more of a mosaic distribution, with no evidence for recent hybridization in the present data. The new morphological and molecular data confirm the presence of an isolated occurrence of T. marmoratus at the north of the Lisbon peninsula and show that the $T$. pygmaeus range follows the coastal zone up to Aveiro and the river Ave in the north, with local climate and soil type affecting the mutual species distribution (Espregueira Themudo and Arntzen, 2007ab; Arntzen and Espregueira Themudo, 2008). The diversity in environmental correlates to the joint species' border illustrates the intricate and complicated relationship of hybrid zone position and the environment, the more so
Figure 7. Geographical clines for DNA sequence data at three nuclear loci $(B F, C A L C, P D G)$ loci and the mitochondrial marker $N D 4$. Haplotypes were pooled into groups that are indicative of the species Triturus marmoratus versus T. pygmaeus. Solid dots represent populations and the grey areas the $95 \%$ credibility interval. The parameters for formal cline descriptions are in Table 3. Note that the character transitions are steep and located at the Tejo river. Clines are coincident and congruent to those in Figure 6, except for the ND4 mitochondrial marker.

if the hybrid zone is, or has been moving northwards. Other congeneric Iberian amphibians and reptiles with to a large extent contiguous range borders show similar - but not coinciding - latitudinal bi- or tripartitions (eg. Alytes Wagler, 1829 - midwife toads; Blanus Wagler, 1830 - worm lizards) (Carretero et al., 2014). Several tripartitions along a longitudinal axis have recently come to light (Pelodytes Bonaparte, 1838 - parsley frogs; Psammmodromus Fitzinger, 1826 - sand lizards). Yet other contiguous congenerics show a distribution mosaic with no particular axis dominating the distribution pattern (Podaris Wagler, 1830 - wall lizards). Given the observed disparity, spatio-temporal correlations between groups are unlikely to exist and evolutionary scenarios for the Iberian herpetofauna will be unique and taxon specific.

\section{Acknowledgements}

I thank Eva Albert, Miguel Carretero, Gonçalo Espregueira Themudo, Elsa Froufe, Nuno Ferrand, Armando Geraldes, Raquel Godinho, Iñigo Martínez-Solano, João Neiva, José Miguel Oliveira, Alexandra Sá-Pinto, Rui Rebelo and Annie Zuiderwijk for assistance in the field or work in the laboratory. I thank the Walen family for hospitality, Rudolf Malkmus for locality information and Iñigo Martínez-Solano and Ben Wielstra for constructive comments on an earlier version of the manuscript. The photographs were made by the late Louis van der Laan, the ink drawings are by Inge van Noortwijk. 


\section{References}

Anderson EC, Thompson EA. 2002. A model-based method for identifying species hybrids using multilocus genetic data. Genetics 160: 1217-1229.

Arntzen JW. 2000. A growth curve for the newt Triturus cristatus. Journal of Herpetology 34: 227-232.

Arntzen JW, Espregueira Themudo G. 2008. Environmental parameters that determine species geographical range limits as a matter of time and space. Journal of Biogeography 35: 1177-1186.

Arntzen JW, Wallis GP. 1991. Restricted gene flow in a moving hybrid zone of the newts Triturus cristatus and $T$. marmoratus in western France. Evolution 45: 805-826.

Arntzen JW, Wielstra B, Wallis GP. 2014. The modality of nine Triturus newt hybrid zones assessed with nuclear, mitochondrial and morphological data. Biological Journal of the Linnean Society 113: 604-622.

Bandelt H, Forster P, Röhl A. 1999. Median-joining networks for inferring intraspecific phylogenies. Molecular Biology and Evolution 16: 37-48.

Barton NH, Hewitt GM. 1985. Analysis of hybrid zones. Annual Review of Ecology and Systematics 16: 113-148.

Buggs RJA. 2007. Empirical study of hybrid zone movement. Heredity 99: 301-312.

Carretero MA, Martínez-Solano I, Ayllón E, Llorente G (2014) Lista patrón de los anfibios y reptiles de España (Actualizada a diciembre de 2014). Asociación Herpetológica Española, Barcelona, Spain.

Cohen J. 1960. A coefficient of agreement for nominal scales. Educational and Psychological Measurement 20: 37-46.

Currat M, Ruedi M, Petit RJ, Excoffier L. 2008. The hidden side of invasions: massive introgression by local genes. Evolution 62: 1908-1920.

Derryberry EP, Derryberry GE, Maley JM, Brumfield RT. 2014. HZAR: hybrid zone analysis using an R software package. Molecular Ecology Resources 14: 652-663.

Diaz-Paniagua C, Mateo JA, Andreu AC. 1996. Age and size structure of populations of small marbled newts (Triturus marmoratus pygmaeus) from Donana National Park (SW Spain). A case of dwarfism among dwarfs. Journal of Zoology 239: 83-92.

Espregueira Themudo G, Arntzen JW. 2007a. Molecular identification of marbled newts and a justification of species status for Triturus marmoratus and T. pygmaeus. Herpetological Journal 17: 24-30.

Espregueira Themudo G, Arntzen JW. 2007b. Newts under siege: range expansion of Triturus pygmaeus isolates populations of its sister species. Diversity and Distributions 13: 580-586.

Espregueira Themudo G, Nieman AM, Arntzen JW. 2012. Is dispersal guided by the environment? A comparison of interspecific gene flow estimates among differentiated regions of a newt hybrid zone. Molecular Ecology 21: 53245335.

García-París M, Arano B, Herrero P. 2001. Molecular characterization of the contact zone between Triturus pygmaeus and T. marmoratus (Caudata: Salamandridae) in Central Spain and their taxonomic assessment. Revista Española de Herpetología 15: 115-126.

García-París M, Herrero P, Martín C, Dorda J, Esteban M,
Arano B. 1993. Morphological characterization, cytogenetic analysis, and geographical distribution of the Pygmy marbled newt Triturus marmoratus pygmaeus (Wolterstorff, 1905) (Caudata: Salamandridae). Contributions to Zoology 63: 3-14.

García-París M, Martín C, Dorda J, Esteban M. 1989. Los anfibios y reptiles de Madrid. Ministerio de Agricultura, Pesca y Alimentación, Madrid, Spain.

Harrison RG. 1990. Hybrid zones: windows on evolutionary process. Oxford Surveys in Evolutionary Biology 7: 69-128.

Héron-Royer [LF]. 1891. Nouveaux faits d'hybridation observés chez les batraciens anoures. Memoires Société Zoologique France 4: 75-85.

Hewitt GM. 1988. Hybrid zones - natural laboratories for evolutionary studies. Trends in Ecology and Evolution 3: 158-167.

IBM SPSS. 2016. Statistical Package for the Social Sciences. SPSS Inc., Chicago, USA.

Leigh JW, Bryant D. 2015. PopArt: full-feature software for haplotype network construction. Methods in Ecology and Evolution 6: 1110-1116.

Mallet J. 2005. Hybridization as an invasion of the genome. Trends in Ecology and Evolution 20: 229-237.

Martínez-Solano I. 2006. Atlas de distribución y estado de conservación de los anfibios de la comunidad de Madrid. Graellsia 62: 253-291.

Michalowski J, Madej Z. 1969. Studies on the relationship of Bombina bombina (Linnaeus) and Bombina variegata (Linnaeus) III. Taxonomic characters in both species from laboratory and in interspecific hybrids. Acta Zoologica Cracoviensia 14: 173-200.

Mystat. 2007. Mystat 12. Systat Software, San Jose, CA, USA.

Petit RJ, Excoffier L. 2009. Gene flow and species delimitation. Trends in Ecology and Evolution 24: 386-393.

Pleguezuelos JM, Márquez R, Lizana M. 2002. Atlas y libro rojo de los anfibios y reptiles de España. Second Edition. Organismo Autónomo de Parques Nacionales, Madrid, Spain.

Prada C, Hellberg ME. 2014. Strong natural selection on juveniles maintains a narrow adult hybrid zone in a broadcast spawner. American Naturalist 184: 702-713.

Pritchard JK, Stephens M, Donnelly P. 2000. Inference of population structure using multilocus genotype data. Genetics 155: 945-959.

Raymond M,RoussetF. 1995. GenePop (version 1.2): population genetics software for exact tests and ecumenicism. Journal of Heredity 86: 248-249.

Sievers F, Higgins DG. 2014. Clustal omega. Current Protocols in Bioinformatics 12: 3-13.

Szymura JM, Barton NH. 1986. Genetic analysis of a hybrid zone between the fire-bellied toads, Bombina bombina and B. variegata, near Cracow in southern Poland. Evolution 40: 1141-1159.

Toews DP, Brelsford A. 2012. The biogeography of mitochondrial and nuclear discordance in animals. Molecular Ecology 21: 3907-3930.

Vallée L. 1959. Recherches sur Triturus blasii de l'Isle, hybride naturel de Triturus cristatus Laur. x Triturus marmoratus Latr. Bulletion Société Zoologique France 31: 1-95.

Wielstra B, Burke T, Butlin RK, Arntzen JW. 2017. A signature of dynamic biogeography: enclaves indicate past species 
replacement. Proceedings of the Royal Society B 284: 20172014

Wielstra B, Sillero N, Vörös J, Arntzen JW. 2014. The distribution of the crested and marbled newt species (Amphibia: Salamandridae: Triturus) - an addition to the New Atlas of Amphibians and Reptiles of Europe. Amphibia-Reptilia 35: 376-381.

Wolterstorff W. 1905. Zwergformen der paläarktischen Urodelen. Comptes Rendus Séances 6 Congrès International de Zoologie, Berne 1904: 258-263.

Received: 5 April 2018

Revised and accepted: 25 June 2018

Published online: 4 October 2018

Editor: A. Ivanović

\section{Online supplementary material}

S1. Allele frequencies at four nuclear loci over 56 populations of Triturus marmoratus and T. pygmaeus in France, Spain and Portugal. Data are in GenePop format.

S2. Marbled newt populations identified to the species with enzyme genetic data in $\mathrm{kml}$ format, for visualization with e.g. Google Earth. Populations are identified as: large green dots - Triturus marmoratus, large red dots - T. pygmaeus and large grey dots admixed. Data are as in Table 2.

S3. Marbled newt populations identified to the species with DNA sequence data in . kml format, for visualization with e.g. Google Earth. Populations are identifies as: small green dots - Triturus marmoratus, small red dots - T. pygmaeus and small grey dots admixed. Data are as in Table 3. 